Portland State University

PDXScholar

9-19-1997

\title{
Korean-American Elders in Independent Living Arrangements
}

Shinok Lee

Portland State University

Follow this and additional works at: https://pdxscholar.library.pdx.edu/open_access_etds

Part of the Korean Studies Commons, Urban Studies Commons, and the Urban Studies and Planning Commons

Let us know how access to this document benefits you.

\section{Recommended Citation}

Lee, Shinok, "Korean-American Elders in Independent Living Arrangements" (1997). Dissertations and Theses. Paper 5374.

https://doi.org/10.15760/etd.7248

This Thesis is brought to you for free and open access. It has been accepted for inclusion in Dissertations and Theses by an authorized administrator of PDXScholar. Please contact us if we can make this document more accessible: pdxscholar@pdx.edu. 


\section{THESIS APPROVAL}

The abstract and thesis of Shinok Lee for the Master of Urban Studies was presented

June 4, 1997, and accepted by the thesis committee and the department.

COMMITTEE APPROVALS
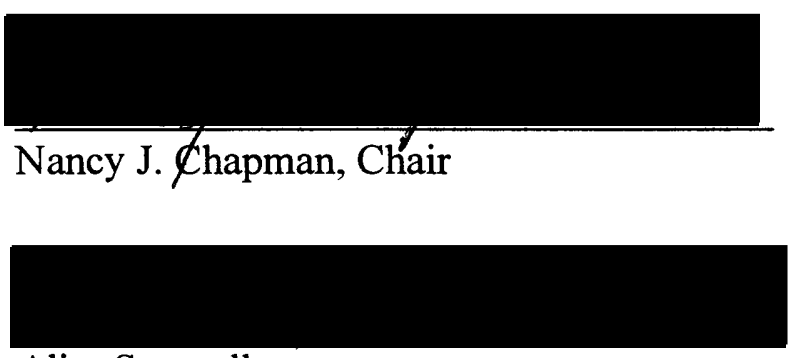

Alice Scannell

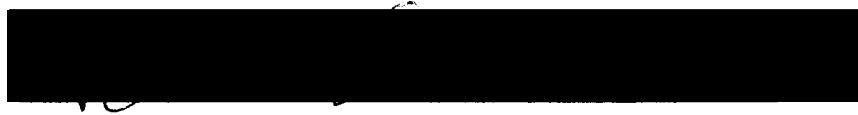

Thomas A. Kindermann

Representative of the Office of Graduate Studies

DEPARTMENT APPROVAL:

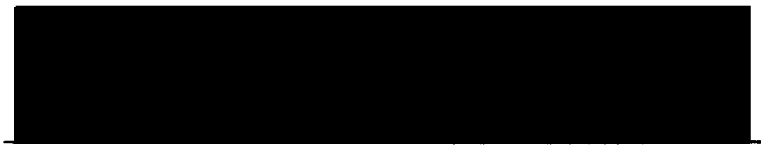

Sy Adler, Chair

School of Urban Studies and Planning

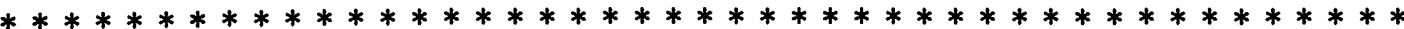

\section{ACCEPTED FOR PORTLAND STATE UNIVERSITY BY THE LIBRARY}

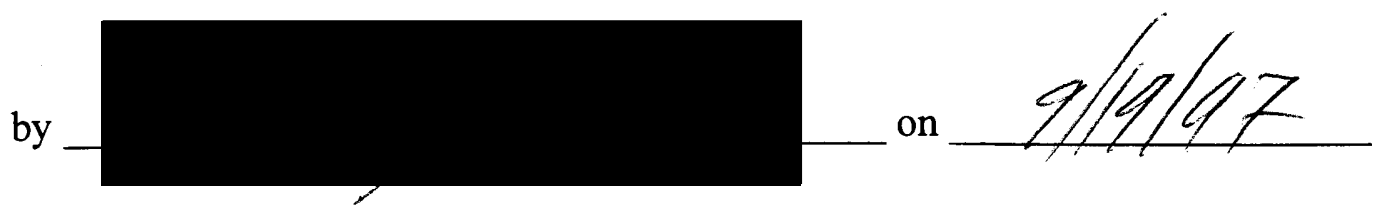




\begin{abstract}
An abstract of the thesis of Shinok Lee for the Master of Urban Studies presented on June 4, 1997.
\end{abstract}

Title: Korean-American Elders in Independent Living Arrangements

Many Korean-American elders in America are new immigrants who are faced with cultural change and adjustment problems. In recent years, these KoreanAmerican elders have been undergoing a change in their living situation by moving away from their adult children into independent living arrangements. This study draws on a sample of 50 Korean-American elders in subsidized housing who are over the age of sixty and live in the Portland, Oregon Metropolitan area to investigate factors involved in their choice of and their well-being in independent living arrangements. Through interviews, the study specifically gives attention to why the elders moved, whether they had the decision power, how satisfied they are with the current situation, how independent they are physically and socially, their self-esteem, and their perceived relationship with their children. I find that the elders feel much more comfortable living on their own and they are more satisfied with the current situation than when living with children. The elders for the most part had the decision power when choosing to move out and they are capable of carrying out the daily activities by themselves. Results suggest that the children are 
the elders' primary helping network, and the elders' self-esteem and their perceived relationship with their children are strong. 
KOREAN-AMERICAN ELDERS IN INDEPENDENT LIVING

ARRANGEMENTS

by

SHINOK LEE

A thesis submitted in partial fulfillment of the requirements for the degree of

MASTER OF URBAN STUDIES

Portland State University

1997 
$\begin{array}{ll}\text { LIST OF TABLES } & \text { iii }\end{array}$

LIST OF FIGURES iv

CHAPTER ONE: INTRODUCTION

CHAPTER TWO: LITERATURE REVIEW 6

$\begin{array}{lr}\text { Living Situations } & 6\end{array}$

$\begin{array}{lr}\text { Asian Societies } & 8\end{array}$

$\begin{array}{ll}\text { Life Challenges for Korean-American Elders } & 14\end{array}$

$\begin{array}{ll}\text { Research Questions and Hypotheses } & 20\end{array}$

CHAPTER THREE: METHODOLOGY 23

$\begin{array}{lr}\text { Sample \& Sampling Procedure } & 23\end{array}$

$\begin{array}{ll}\text { Interview } & 24\end{array}$

$\begin{array}{ll}\text { Demographic Variables } & 24\end{array}$

$\begin{array}{ll}\text { Variables } & 27\end{array}$

Methodological Problems 31

CHAPTER FOUR: RESULTS 33

$\begin{array}{ll}\text { Demographics } & 33\end{array}$

Research Questions and Hypotheses $\quad 36$

CHAPTER FIVE: DISCUSSION AND CONCLUSIONS 52 
Factors Involved in the Decision to Move

Factors Involved in the Decision to Move

Satisfaction with Living Independently

Relationship with Children

Functioning Independently

Social Network

Self-Esteem

Strengths and Limitations of the Study 60

Future Research 60

REFERENCES

APPENDIX A: Interview Questionnaire Used in English 64

APPENDIX B: Introduction Letter, Consent Form and

Interview Questionnaire Used in Korean

APPENDIX C: Correlation Matrix 


\section{LIST OF TABLES}

Table 1. Demographics

Table 2. Factors Propelling Elders Toward An Independent

Living Arrangement

Table 3. Frequency Distribution of Responses to

Relations with Children Questions

Table 4. Percentage of Elders Who Can Carry Out

IADL by Themselves

Table 5. Social Network Distribution- Who the Elders Call

When They Are In Need 


\section{LIST OF FIGURES}

Figure 1. The Elders' Perception of Children's Feelings on Their

Parents Living In Independent Living Arrangements

Figure 2. Current Level of Satisfaction Compared to Living

With Children

Figure 3. Distribution of Elders' Perceived Relationship With

Children Scale

Figure 4. Distribution of Elders' Self-Esteem Scale 


\section{Introduction}

As more people live longer, stronger emphasis should be placed on the quality of life in later years. With a growing population of elderly people in the United States, more people are concerned for the well-being of this group. Brown (1990) states,"... that the situations or conditions of their daily lives are central to their sense of well-being." Interestingly, an increasing number of the KoreanAmerican elders, who are faced with adjustment problems, are changing their living situations (Han, 1986). They are choosing to live separately, independent of their adult children upon whom they have been dependent. As a neglected segment of the elderly population who are growing in number and are facing changes in the family structure and social environment, attention must be given to the well-being of these Korean-American elders who are in independent living arrangements. Although these elderly people are living independently, are they really capable of independent living functionally, socially, and emotionally? What are the factors related to the KoreanAmerican elders choosing to live independently away from their adult children? Are they satisfied with the decision they have made to move out?

Among immigrants, Koreans have immigrated to the United States at the fastest rate in the 1980's, with the exception of Mexicans and Filipinos (Koh \& Bell, 1987). Koreans became a distinct ethnic group in the U.S. Census in 1970 even though the first wave of immigrants, numbering some 7,000 people, came to America during the period of 1902-1905. In the 1970 U.S. Census, out of a total of 70,598 
Koreans in the U.S., 3,270 persons or $4.6 \%$ were reported to be 60 years of age or older. By 1980 the total number of Koreans had increased more than five times to a total of 354,593 , of all ages, of whom 14,616 or $4.1 \%$ were aged 60 years and older (Koh \& Bell,1987). Currently, among the 7,273,662 Asians and Pacific Islanders, Koreans are the third fastest growing subgroup and make up $10 \%$ of that population according to the 1990 Census (U.S. Bureau of the Census, 1991). Approximately $6-7 \%$ of the Korean-American population is 60 years of age or older.

Throughout the literature on Korean-American elders, the Korean-American elders are portrayed as having many obstacles to be living independently. The majority of the Korean-American elders are recent immigrants to the United States. The elderly immigrants did not come to the United States for occupational or individual reasons. They were sponsored by their children so that they could keep the family union, and they are unaccustomed to the American ways of life (Koo, 1981). Lack of English proficiency, poor health conditions, loneliness, no transportation, low/no income, and insufficient housing are six major apparent problems the Korean-American elders face (Koh \& Bell, 1987). These elders are dependent on their children who are more adept with American lifestyle.

Despite the dependency, a study found those Korean-American elders who are living with their children's family to be dissatisfied with the living arrangement (Kim et al., 1991). A study by Han in 1986 showed that many Korean-American elders found independence by moving out to government-subsidized housing. The 
study further found that the majority of those elders who still lived with their children wished to move out to an independent living arrangement.

The indication of the Korean-American elders desire to move out of the children's homes is an ironic phenomenon since the elders come from a traditional patriarchal background and they hold a traditional expectation of filial piety. According to several studies, the cause of the strain in the intergenerational relationship between the elders and their children is that the children do not adhere to the traditional ways and do not give elders the respect and honor required by norms of filial piety. Kang \& Kang (1983, p.47) depict the situation as such:

...the Korean elderly are not served by their children; instead they have to serve their children. They find their status reduced to that of "housekeeper." Most of them no longer have control over socially valued resources based on economic or political power, or traditional age-related authority. They are no longer consulted about family-related affairs by their children. Since they do not understand English and are not familiar with the management of their daily lives, they need assistance with matters which range from immigration and social service needs to transportation to churches. In this circumstance, the elderly's initial high expectations soon turn into disillusionment and frustration. They see their status greatly diminished in the family as well as in the new environment of the ethnic community. According to Kim et al. (1991), when the Korean-American elders view their relationship with their children from the perspective of traditional expectations, they 
probably feel they are "neglected, slighted, and humiliated." This study further explains that it is extremely difficult for Korean immigrants to practice the traditional filial piety due to changing life conditions. The irony lies in the Korean-American elders' desire to uphold traditional expectations at the same time they express a strong desire for a non-traditional living arrangement.

Currently, many Korean-American elders are living in a non-traditional living arrangement (Han, 1986). They are living independent of their adult children in government-subsidized housing generally. The factors involved in propelling the elders to move out to independent residences can be speculated on, but there have not been any actual studies. Why did they move out? The study by Han (1986) did find out that more than 90 percent of the elders who maintain independent residences actually liked the living arrangement. The question whether the KoreanAmerican elders in an independent living arrangement are satisfied with the decision to live independently may be complex rather than simple. Do they perceive a positive relationship with their children? Are they still very much dependent on their children even though they are in an independent living arrangement? How is their self-esteem?

It is important to find out how the Korean-American elders in an independent living arrangement are doing. It is the goal of this investigation to understand the experiences of the Korean-American elders in independent living arrangements in light of their cultural background and conceptual framework of 
quality of life. Specifically, I will focus on physical functioning, self-care, selfesteem, and social functioning. 
Chapter Two

Literature Review

\section{Living Situations: Independent vs. Extended Family}

The living situations of the aged vary cross-culturally, but Arnold Brown (1990) states that historically and cross-culturally three-generation households were the most prevalent living situations for the elderly. The three-generational household is what we define as the original extended family. The living situation in which the original extended family lives together still persists in Asian countries, in Eastern European countries, and in many developing countries of the world. This living situation existed in Western societies when the family was the central social and economic structure, but it is not prevalent anymore at this time. The changes came to some countries earlier than others. Brown (1990) gives four reasons why the original extended family prevails more in some cultures: (1) religious/ideological traditions, (2) certain social and economic structures, (3) practical realities, and (4) a combination of these factors.

On the other hand, there are other researchers who refute the idea that a fully extended family existed at all in the Western historical past. Baum and Baum (1980) cite Laslett and Furstenberg (1977) as questioning whether the extended family was ever prevalent in the West prior to industrialization. People did not live long enough to see more than two generations living together and life expectancy did not begin to increase until the first decade or so of the twentieth century. Then came 
industrialization which brought what Goode (1963) referred to as the "conjugal" or "modified extended" family. The emphasis switched from lineage to marriage bonds, increasing the importance of the wife's family.

Fischer (1978) makes the point that the "revolution in age relations" began before industrial development and spread throughout the world. He contends that the changes in intergenerational relationships were brought on by a new set of values rather than by economic development. Specifically, the belief in 'equality' and individual 'liberty' is where the impetus for independence originated, and this belief system changed the lives of Americans in the mid-nineteenth century.

Along with the notion of striving for independence, industrial development in the West brought modernizing processes and economic development, which caused changes in the pattern of the living arrangement. Leslie and Korman (1985) describe the elderly people, especially older men, in the original extended family as being in control of the social and economic structure. Then the industrialization process enabled the younger people to be economically and socially independent, and the aged became "dependent upon their children instead of the other way around" (Brown, 1990). In line with the idea in "the revolution of age relations," the elderly desired independence even more than the younger generation. The importance of this factor for the elderly is reflected in their choice to set up separate living quarters from their children. As Quinn \& Hughston (1984) stated, perhaps "independence for many older persons is a realistic idea that catalyses a wide range of possibilities in promoting quality of life." 


\section{$\underline{\text { Asian Societies }}$}

Stokes (1992) formulated the terms of aging as an [age * culture] interaction. Throughout the literature, Asian societies are credited as a culture that nurtured conventionalism and unity rather than independence in the past. Strong cultural traditions of filial piety have especially contributed to three-generational households in China, Japan and Korea and other Asian societies influenced by Confucian culture (Kim et al, 1991).

\section{Changes in China and Japan}

However, the pattern is shifting toward conjugal family orientation even in countries with a patriarchal background. Japanese elders still live with their adult children's families for the most part, but the trend is moving away from the original extended family. An increasing number of elderly are living separate from their children. Also, more adults who are both taking care of their parents and raising their children are expressing a sense of burden (Brown, 1990).

In China, the communist takeover in 1949 broke up the traditional foundation for original extended family. The Chinese Communist Party brought with it the notion of equality that served to undermine the patriarchal authority of Chinese elders (Brown, 1990). The government provided jobs for the young people and marriage laws encouraged choosing mates without regard to family wishes. Due to the long tradition of filial piety that is embedded in the culture, the original extended family has remained although the structure of authority and responsibility has changed. Financial resources are equally owned by all members, and household 
duties are equally shared. Davis-Friedmann (1983) reports that some Chinese elders were rejected as household members by their adult children, but Brown (1990) emphasizes that as China becomes more affluent, the nuclear family will be more likely to replace the extended family.

\section{$\underline{\text { South Korea }}$}

Traditional filial relationship. Korea was heavily influenced by Confucianism (Chung, 1995). According to the Confucian idea of human nature, a person becomes human only in the community of people. To be human is to act morally in the community of people according to virtues, moral righteousness, modesty, and a sense of shame. Without these four, human beings remain not much different from the "beasts" (Chung, 1995).

In the traditional Confucian notion, the continuation of the extended family and its needs were more important than the individual and the nuclear family. The dominance of children by their elders was an important issue as well. The aged must be respected according to the notion entailed in filial piety. A respectful attitude was deemed necessary toward all elderly persons (Sung, 1992). Filial piety extends to the neighborhood and society. In any setting, if an elderly person is present while all seats are taken, it is expected that a younger person will give up his/her seat for the elderly person.

A son owes his parents material and spiritual support in his parents' old age. Throughout the life of the parent, oldest son is to live with them and provide everything he is capable of providing. Kim et al (1991) summarizes the filial piety 
obligations as: (1) physical care, (2) social-psychological comfort, (3) respect for and consultation with parents concerning important family and personal matters, (4) honoring and glorifying parents through the son's outstanding achievement, and (5) faithful observance of important ceremonial occasions.

However, there is a saying that one never repays one-thousandth of his obligations to his parents (Sung, 1992). It is essential to keep harmonious relations between generations. Sung states that "...the family relations, affection, and fraternity take on great importance." Care for aged parents is not an option but a moral responsibility. Neglect of one's parents is considered unethical and immoral, a breach of traditional values and customs (Koh \& Bell, 1987). A core ideal of filial piety is that the child would do everything for the elder's safety and health. Even a long distance trip should be refrained from if it gives parents anxiety (Sung, 1995).

A filial child must be able to think of family first. Even in language usage, "our" is more often used than "my." Ancestor worship and the keeping of the genealogy which are practiced in Korea, reinforce this orientation. The filial child will carry out the wishes of his father and carry forward his unfinished undertakings. The oldest adult son is responsible for his elderly parents since the society is based on the primogeniture system. Thus, the first sons, even after they marry, traditionally stay with their aging parents in their homes until the parents die (Youn \& Song, 1991). Confucius said, " That parents, when alive should be served according to propriety; that when dead, they should be buried according to propriety (Sung, 1995, p.241)." 
Present trend in Korea. In South Korea, where filial piety has been a tradition throughout history, the pattern of the original extended family has been changing to a modified extended family since the early 1960's. Currently about one third of Korean elders is not living with their children (Youn \& Song, 1991). Nonetheless, K.T. Sung (1995) found that the tradition of filial piety persists. Koreans will likely continue this cultural tradition in one form or another. Sung (1995) quotes The Book of Rites which states that three important conditions for filial piety are: (1) respecting one's parents, (2) bringing no dishonor to parents and family, (3) taking good care of parents with good food, soft clothes, a warm room, comfort, and peace.

According to K.T. Sung (1992), about $80 \%$ of Koreans provide parental care in the family context. There have been nationwide efforts to enhance respect and care for Korean elders through the enactment of laws for the elders' welfare, provision of social and health services for the elders, and the establishment of "Respect for the Elderly Week" and the "Filial Piety Prize System" (Sung, 1995). The efforts emphasized tangible services but lacked the qualitative aspect of care such as "respect, responsibility, and sacrifice for parents" (Sung, 1995). Providing services does not guarantee that the elders receive the support for filial piety, but at least it directs the nation's efforts toward the welfare of the elders.

Although K.T. Sung (1992, p.115) summarized the five main categories of filial motivation from children's responses as, "...putting their family members in harmonious order, the filial persons cared for their parents with respect, and responsibility, having the desire to repay, while making sacrifices for their parents." 
Youn \& Song (1991) found that the young generation does not try to understand elders' distress and loneliness. The gap between ideals of filial piety and practice is another stress factor for both the elders and the children.

Korean elders and their children. Youn \& Song (1991) suggest that adult children are an important source of emotional well-being for widowed Korean elders. However, there are inevitable conflicts between elders and their children. In a study of Korean elders' perceived conflict with their children, bereaved elders who lived with their children perceived the most disrespect while the married elders who lived independent of their adult children perceived the least (Youn \& Song, 1991). Regardless of the living situation, the Korean elders expected a qualitatively better relationship with their children as they grew older. But, with increased age, elders' perceived conflicts and problems in the relationship with their children increased. It can be inferred that as elders grow older and their expectations of their relationship with their children increase, but if children's helping efforts remain constant, perceived conflicts or disappointment with the children may increase.

Urbanization and role change. Some aging Koreans do not want to live with their children's families because they anticipate discontent with their new roles. The cause for this change has been attributed to Westernization and urbanization. Modernization includes factors such as "modern mass education, the decreased importance of nuclear family, retirement, residential segregation between generations, social differentiation, and rapid change of the social structure and cultural value system (Hong \& Keith, 1992, p.197)." In recent research on the effects of 
modernization process on the elderly, it has been hypothesized that the status of the aged will decline as a society becomes more modernized and developed. In the past, the elder played the role of a guardian, but in the contemporary setting they are the ones in need of protection. Youn \& Song (1991) think that a situational change that brings a role change may cause the Korean elders psychological distress and loneliness.

Elders' status and decision making power. The way elders receive respect has been slowly changing in Korea. This change may be due to the movement toward the nuclear family, the increasing number of women in the labor market, the geographic mobility of villagers, and the trend toward more individualistic lifestyles (Hong \& Keith, 1992). Hong \& Keith explain that "salaried employment has become an important source of family income and a major element in social status. Young people who are employed become economically independent from their parents and they tend to reject the traditional values of obedience, respect, and deference toward the aged." Modern society sets the stage for the nuclear family. In this setting the familiar role of the elder as an adviser has become ambiguous. A study of Koreans over 60 found that despite the extended family living situation, only $27 \%$ of the children discussed possible choices with their parents before making important family decisions, and $31 \%$ of the children ignored their opinion (Park \& Lim, 1983). Also those elders who keep pace with modernization retain their respected status and stay in the position of protecting and governing their offspring. For those elders 
who are not modernized, their decision making power in the family declines (Hong \& Keith, 1992).

McPherson (1983, p.150) summarized the causes of the elders' lowered status as follows:

1. The introduction of modern technology increased longevity and led to intergenerational competition and retirement.

2. The development of modern economic technology made the jobs of the aged obsolete and led to new occupations in urban environments.

3. The onset of urbanization led to migration and to social segregation by age and socio-economic status.

4. The increased level of educational attainment with each subsequent generation enabled children to become better educated than their parents and grandparents.

\section{$\underline{\text { Life Challenges for Korean-American Elders }}$}

Elders who are finding more challenges in keeping up with modernization will find that immigration brings more obstacles to their struggle. According to Kiefer et al. (1985), immigration, particularly from a non-Western culture, often has serious psychological effects that make adjustment a higher priority than modernization. The language barrier is one distinct disadvantage in the adjustment process. Studies show that elderly Korean immigrants face multiple adjustment problems: culture shock, insufficient information about health and legal services, lack of control over 
their living circumstances, severe financial problems, loneliness, and transportation problems (Kiefer et al, 1985; Kim et al, 1991).

The immigrant status generally signifies three types of disadvantageous experience: (1) The substantial loss of pre-immigration socio-economic resources or ties, (2) the continuous attachment to significant parts of their preimmigration lifestyle and belief system, (3) and the limited experience of Americanization (Kim et al, 1991). According to Kim et al, older Koreans in the United States generally keep their ethnic, social, and cultural ties regardless of length of residence and as a result, they do not speak English and are not familiar with the American way of life and social system. Naturally, the Korean-American elders become dependent on their children.

The social conditions of Korean-American elderly parents create a serious gap between "the expected role of respected elderly" and "the reality of degrading housekeeper (Kang \& Kang, 1983)." The Korean elderly immigrants grew up in a traditional Korean society. When they see their relationship with their married children's family from the perspective of traditional expectation, they probably feel they are neglected and humiliated in their children's homes. Many of the parents feel they are not taken care of physically. They are neither respected nor consulted on important family matters. When elderly parents are only marginally Americanized, it is doubtful that they can offer any meaningful advice to their children, even though the children want to consult with them. It takes a considerable amount of time to explain the situation to the parents. The elderly parents' suggestions or advice are 
considered as interference with the children's family affairs; they are resented and regarded rather as unwanted advice. The parents will eventually feel they are marginal persons in their children's homes (Kang \& Kang, 1983).

$\underline{\text { Korean-American Adult Children's View }}$

The Korean-American adult children hold the traditional patrilineal extended family system in ideology. Married children expect that their aged parents will live with them whenever necessary if they are not living with them already (Kim et al, 1991). Kim's Chicago study in 1986 demonstrates this fact. Three-fourths of Korean immigrants in the sample believed that the wife should treat her parents-inlaw as her own parents. Filial piety is embedded deeply in the minds of most Korean immigrants.

However, the conditions of immigrant life pose obstacles for Koreans fulfilling their traditional filial expectations. The immigrant families have to work long hours, and the traditional family system has been considerably weakened (Kim et al, 1991). Virtually all the husbands and a great majority of the wives are working in order to support their family. They are generally employed in jobs that require unusually long hours like grocery stores, dry cleaners and laundromats, restaurants, etc. Under these conditions, the parents are expected to help with housework in their children's home, babysitting, or the management of their children's small business (Kang \& Kang, 1983, Kim et al, 1991).

Adult children's sense of filial obligation in the United States is considered a matter of personal attitude or option, but Korean-American elders perceive it as a 
culturally-sanctioned normative obligation. When the Korean-American elders move out or express their desire to move out, their adult children are generally embarrassed by such a desire on their parents' part and will prevent them from doing so as much as possible. If the parents move out, the children fear that it is a public admission that they did not take care of their parents well (Kim et al, 1991). Kim contends that when the original extended family gives way to the conjugal family, the nature of filial obligation should also be modified in Korean immigrant families.

\section{A non-traditional trend}

To Korean-American elderly parents, fulfillment of the traditional filial piety is expected. However, due to the previously mentioned bleak social conditions of immigrant life, expectations of the tradition severely strain intergenerational relationships between elderly parents and married children and their spouses. An indication of a tense relationship is the elderly parents' desire to move out of their children's homes and establish their own independent residences. Independent living arrangements allow the parents to avoid being subjected to the children's arbitrary treatment and neglect. They also give room for independence and privacy, which in turn helps to minimize the conflict between the aged parents and their children (Kim et al, 1991). However, Korean-American elderly parents' preference for an independent residence contradicts their traditional belief and lifestyle. The intergenerational strain comes from the elder's intolerance of non-traditional behavior in the original extended family, but the elder desires a non-traditional living arrangement. 
Isolation and independent living. Some parents also feel isolated in their children's homes, particularly in suburban areas. Demographically, those persons who are at greatest risk of difficulty in psychosocial adaptation and isolation are those who have little education, and have arrived in the United States recently (Week \& Cuellar, 1983).

In studying the alienation of elderly Korean American immigrants, Moon \& Pearl (1991) found that size and cohesiveness of ethnic community and length of stay in the United States have an inverse relationship with feelings of alienation. The study did not find any significant relationship between gender, years of education, and whether participants lived with their children.

Contrary to this, Kiefer et al (1985) found that elderly living in an original extended family often had problems with crowding, overwork, and strained social relationships, yet they tended to exhibit more positive morale and better self concepts than those who lived alone or with a spouse only.

Week \& Cuellar (1983) predicted that the size of the natural helping networks influences the isolation of older persons. Moon \& Pearl (1991) speculate that elderly Korean immigrants tend to feel isolated from their Americanized children by a generational gap and come to rely socially more on their spouses. Another study indicated that in times of need, the Korean-American elders' most preferred sources of help were spouses and children, but a substantial proportion (one-third) of the respondents indicated they looked to formal social services (Koh \& Bell, 1987). This is an aberration from the traditional filial relationship. 
Independent residences. Many elderly Korean immigrants have established an independent residence by taking advantage of government subsidized low rent apartments. Kim et al (1991) cite a study by Han (1986) that shows that more than 90 percent of the elderly parents in independent residences are satisfied with the arrangement. Even the majority of those elderly parents who currently live with their children wish to move out of their children's homes and establish their own residences. Compared to the less than 17 percent of the South Korean elderly who expressed the desire to live apart from their children, about 70 percent of the New York sample of Korean American elders indicated a desire for separate households (Koh \& Bell, 1987). Kang \& Kang (1983) termed those Korean-American elderly who actually find independent residences as the "innovators." When the elders become eligible for public benefit programs such as SSI, and Medicaid, they often move out and set up independent living arrangements in apartments in an ethnic neighborhood or a senior citizens' housing unit (Kang \& Kang, 1983). Although they maintain contact with their children, "intimacy at a distance" might best describe this situation. They attain and maintain this arrangement not through control over economic or social resources or traditional age-related authority, but through access to public benefit programs (Kang \& Kang, 1983). With the passage of new legislation in 1997 that removes welfare eligibility for legal residents who are not U.S. citizens, some of these elders may be in danger of losing the privilege of choosing the independent living arrangement. 
Research Questions and Hypotheses

Do the Korean-American elders in an independent living arrangement have a good quality of life? According to Ronald Abeles (1994), the domains in the conceptual framework of quality of life include: physical functioning, selfmaintenance, usual activities, social functioning, intimacy, psychological well-being, cognitive functioning, pain and discomfort, energy/fatigue, sleep, self-esteem, sense of mastery/control, perceived health, and life satisfaction. In order to replicate the findings in the literature review and understand the well-being of the KoreanAmerican elders in an independent living arrangement, I examine the following research questions and hypotheses.

Research Question One: What factors are involved in the decision of KoreanAmerican elders to move into subsidized housing?

I explore the respondent's history of residence, what influenced them to move to where they are now, their decision making power, and their family's reaction before and after the move.

Research Question Two: Are Korean-American elders satisfied with living independently?

Although independent living arrangement violates the filial tradition that is deeply embedded in the Korean culture, the Korean-American elders will find it satisfying to be living away from their children.

Hypothesis One: Korean-American elders are satisfied with the independent living arrangement. 
Research Question Three: What is quality of the relationship between KoreanAmerican elders and their children?

The children are the primary support group for the Korean-American elders, and the elders rely on the children for emotional support. However, there are cultural and generational gaps between Korean-American elders and their children. The elders who are living independently do not want to live with their children. The independent residence makes contact with friends easier.

Hypothesis Two: Korean-American elders in independent residences do not hold a positive view of their children's values and of their intergenerational relationship.

Hypothesis Three: Korean-American elders would prefer not to live with their children.

$\underline{\text { Research Question Four: To what extent are Korean-American elders living in }}$ subsidized housing able to function independently?

Hypothesis Four: The Korean-American elders in independent living are dependent on others for carrying out some of their Instrumental Activities of Daily Living (IADL).

Hypothesis Five: Those who are more fluent in English will be more independent in carrying out IADLs.

Hypothesis Six: They are socially dependent on their children, rather than relying on other resources such as friends, neighbors, formal aids, their spouse, or themselves. 
Research Question Five: How is the self-esteem of the Korean-American elders living independently? How does their relationship with their children influence selfesteem? How do demographic variables affect self-esteem?

Feeling isolated and lonely can be reflected in a person's self-esteem. Certain demographic variables affect the feeling of isolation, thus self-esteem.

Hypothesis Seven: Korean-American elders living in subsidized housing do not have a high self-esteem.

Hypothesis Eight: The length of stay in the United States and level of education will be positively related, while age will be negatively related, to high selfesteem.

Research Question Six: What predicts the satisfaction of Korean-American elders with independent living?

Hypothesis Nine: The elder's perceived positive relationship with their children will be positively related to their satisfaction with living independently. Hypothesis Ten: The length of stay in the United States, gender, decision power, length of stay with children, reasons why they decided to move and desire to live with children in the future are significant predictors for satisfaction with independent living. 
Chapter Three

\section{Methodology}

Sample \& Sampling Procedure

The sample is drawn from ethnically dense public housing facilities where there are more than thirty Korean-American elders residing in the same apartment complex. They are living in a city that has a large Korean population, with six Korean grocery markets, six Korean video rental shops, one Korean radio station, four Korean newspapers, and more than thirty Korean churches and a temple.

To examine and test the preceding research questions and hypotheses, I used the data collected from interviewing 50 Korean-American elders living in government subsidized housing in the Portland Oregon Metropolitan area. The data were collected in the following manner. Lists of Korean-American elders living in independent living arrangements were obtained from managers of the 1200 Building, Kirkland Union Manor and Beaverton Apartments. Also a list of the Korean Seniors Association members were obtained from the Korean Mealsite Coordinator which had some duplicates of the individuals from the housing list. A letter of introduction and explanation was mailed out to the eighty possible respondents and a follow-up phone call was made to sixty-six elders to set up appointments for the interviews. The refusal rate was $24 \%$.

\section{Procedures}

The interviewers included the researcher and a trained interviewer, both of whom speak Korean fluently. The interview was always conducted in Korean and in 
the elder's apartment. The interviewer made notes on the prepared questionnaire form as the respondent answered the questions and each interview lasted around 45 minutes.

Interview

The questionnaires had been translated into Korean through a pilot study with opinions from the participants as to the culturally appropriate wording of the questions. The pilot study participants included the researcher's father and two other Korean-American elders living in a subsidized housing. Once the questionnaire was formulated in English, the researcher met with a Korean-American housewife who was a former teacher in Korea to translate the questionnaire. Then the Korean version was pretested on the researcher's father first and then on the other two elders before the actual interviews were conducted.

The interview discussed the following topics: demographics, factors that influenced the decisions to move to the independent situation, families' reaction to the decision, satisfaction with the decision, desire to live with children in the future, level of independence to carry out daily activities, social network, self-esteem and relations with children. Appendix A provides the exact wording of questions used.

\section{Demographic Variables}

\section{Gender}

The interviewer coded male respondents $=1$ and female respondents $=2$. 
Age is a measurement of the respondent's age. The respondent's birthdate was asked and the age was determined from the interview date.

$\underline{\text { Marital Status. }}$

Married=1, widowed=2, or divorced/separated $=3$.

Reason for Move to the U.S.

The primary reason for deciding to come to the United States were coded as follows: Job for self or spouse $=1$, children $=2$, or other $=3$.

\section{Past Occupation.}

The respondents were asked to describe their primary occupation in the past, including housewife. The answers were categorized as follows: Housewife=1, business $=2$, farmer $=3$, or other $=4$.

$\underline{\text { Level of Education }}$

Total years of schooling completed by the respondent were coded for this measurement.

\section{$\underline{\text { Residential Status }}$}

Respondent's residential status were coded as follows: U.S. citizen $=1$ or permanent residence $=2$.

Length of Stay in the U.S.

Number of years the respondent has been in the United States was measured from the interview date.

Length of Stay in Portland Area 
Number of years the respondent has been in the Portland area was measured from the interview date.

Have Children

Whether the respondent has any children was coded as follows: Yes $=1$ or no $=2$.

$\underline{\text { Have Lived with Child }}$

Whether the respondent ever lived with an adult child was coded as follows: Yes $=1$ or $n o=2$.

Length of Stay with Children

For those who had lived with children in the past, the number of years the respondent lived with a child was measured.

\section{Length of Stay in Current Address}

The number of years the respondent has been living in the current address was measured.

Prior Place of Residence

Where the respondent lived before moving to the current address was coded as follows: In another senior housing $=1$, in a house/apartment by oneself or with spouse $=2$, and in children's house $=3$, or other $=4$.

English Fluency

The level of English comprehension was measured by asking how well the respondent understands when spoken to in English by the manager, neighbor or others. The respondent was given five choices: Not at all $=1$, Almost not at all $=2$, 
about half $=3$, moderately well $=4$, or fluently $=5$. The ability to speak English was measured by asking how well the respondent can express him- or herself in English. The respondent was given five choices ranging from not at all $=1$ to fluently $=5$.

\section{Variables}

\section{Factors Involved in the Decision to Move}

\section{Reasons for Moving Away}

To understand the factors involved in the Korean elders' decision to move away from their children, first an open ended question was given: "What influenced you to move here?" The answers were categorized and tabulated as follows:

Comfort $=1$, social $=2$, transportation $=3$, church $=4$, not enough rooms $=5$, no income $=6$, independence $=7$, or other $=8$.

Having Other Koreans in the Building Influence Decision

The respondents were asked whether they would have moved there even if there were no other Koreans in the building: yes $=1$ and no $=2$.

\section{Decision Making Power}

The question, "How much say did you have in your decision to move here?" was asked to determine how much decision power the elders had in the matter. Respondents were given three choices: none at all $=1$, some say $=2$, or complete say $=3$.

\section{$\underline{\text { Family's Reaction }}$}


Two open-ended questions were posed as to how the family felt when the respondent first decided to move out independently and how the family feels about it now that the respondent has been living independently for awhile. The answers were ranked on a four point scale (ranging from good=1 to $\mathrm{bad}=4$ ).

\section{$\underline{\text { Satisfaction with Living Situation }}$}

The question "When you compare your current living situation to when you were living with your children, how satisfied are you now?" was asked to determine their level of satisfaction with their decision. This was measured on a five point scale ( ranging from very dissatisfied $=1$ to very satisfied $=5$ ).

\section{Ability to Function Independently}

In order to measure their independence, the elders were asked whether they did laundry, housework, cook, buy medication, and manage money by themselves (all the time $=3$, sometimes $=2$, or not at all $=1$ ). The percentage in each category is tabulated to come to an understanding of their level of physical independence.

\section{Social Network}

\section{Who's Most Helpful}

The elders were asked who they think is most helpful in providing for the needs of the senior citizens. They were given nine categories of people to pick from : children, other relatives, friend or neighbor, clergy or church member, government, Korean Elders Association, self or spouse, other (manager), don't know (no one). The answers were tabulated as to the number of times the elders named a certain category. Who Would You Call 
To understand the informal social support networks for the elders, the respondents were asked to pick who they would call if they were sick, needed a ride, needed a loan, were upset, needed to borrow sugar or hot-pepper, move furniture, change a lightbulb, get advice on a major change, go shopping, and for fun. The elders were encouraged to name upto three people, but very few gave more than one answer. The elders did not want to give the names of their network but just gave the relationship of the person. The answers were then categorized in the same manner as above with the exception of a differentiation between self and spouse. For each of the ten situations, the number of times the elders named a certain category of people was tabulated to denote whom the elders depend on most in each situation. The respondents were also asked where the helper lived, and how often they saw them.

\section{$\underline{\text { Self-Esteem }}$}

To measure self-esteem, Rosenberg's self-esteem test was utilized. "Selfesteem, as noted, is a positive or negative attitude toward a particular object, namely, the self. High self-esteem as reflected in our scale items, expresses the feeling that one is 'good enough.' One might consider using the term "self-acceptance" to describe these people.... Low self-esteem, on the other hand, implies selfrejection, self-dissatisfaction, self-contempt" (Rosenberg, 1965). There are five positive questions and five negative questions on a four point scale (strongly agree=1 to strongly disagree=4). The scores of the five positive questions were added up and then divided by five, and this final score was inverted so that a high score equals high self-esteem. The scores of the five negative questions were added up and also 
divided by five. The positive and negative scores were then added and divided by two to arrive at the elders' self-esteem score. Self-esteem score is used as a dependent variable indicating the elders' general satisfaction with the decisions they have made and a general impression of oneself and psychological well-being. (See Appendix A for the questionnaire).

\section{$\underline{\text { Relationship with Children }}$}

The elders' perceptions of the relationship with the children are framed in the same manner as for the self-esteem; there are ten questions measured on a four point scale (from strongly agree $=1$ to strongly disagree $=4$ ). The five positive questions and five negative questions range from whether the elders feel comfortable with the way their children do things to whether the children come to them for advice and whether they have a desire to be a part of or influence children's lifestyle. The positive questions were framed to show satisfaction with the way things are and the elder's desire to continue the active interaction with the children. The negative questions were framed to denote the elder's desire for a change, being indifferent or withdrawn from interacting with the children. (See Appendix A for the questionnaire). The scoring procedure is the same as for self-esteem. (i.e., the positive and negative scores were tabulated and the two scores added and then divided by two, in order to attain the score as to how the elders perceive their relationship with their children).

\section{Prefer to Live with Children in the Future}

The elders were asked if they wish to live with the children in the future. They were given three choices: yes $=1$, only if I have to $=2$, or no $=3$. 
If Living with Children, Elders Would Help

The elders were asked if they were living with the children's family, what kind of work or support they would have to do for the family. Five choices were given: Financial $=1$, babysitting $=2$, housework $=3$, other $=4$, or none $=5$.

\section{Methodological Problems}

Most Americans have become accustomed to public opinion surveys, but most older Korean-Americans have not been interviewed for social research purposes. At the research proposal stage, I had planned to interview KoreanAmerican elders living with their children as a comparison group to the KoreanAmerican elders who are living in an independent living arrangement. First of all, it was difficult to find enough elders who are living with the children to consent to interviews. Although told that the information given will be anonymously tabulated and that the information will be used only for study purposes, the elders excused themselves by saying they do not have anything to offer in several instances. I narrowed down my sample just to the elders in an independent living arrangement and asked questions on satisfaction after moving out independently.

Overall, I believe the respondents were honest with me. Several people said that they do not need to hide anything and want to share what they know and feel so others will know how elders feel. However, on certain culturally embedded value questions, typically from the self-esteem questions, (questions like "I feel I do not have much to be proud of"), some of the respondents who answered "agree" 
indicating a negative affect score later added that they could not be boastful and say they are proud of something.

Overall, I found the respondents to be very willing to help. When I explained that the interviews were for my thesis, some people wanted to make sure I found enough respondents because they value education. Several people personally assisted me to other elders' homes when I could not reach them over the phone.

In sum, my thesis endeavors to analyze Korean-American elders who are living in an independent living arrangement and to understand their overall well-being. In the next chapter I provide the results from the analyses of the previously introduced factors. 
Chapter Four

Results

\section{$\underline{\text { Demographics }}$}

The first step in this investigation is to provide a demographic description of the sample of Korean-American elders in subsidized housing. The majority of the respondents were female, and over $60 \%$ of the sample was in the 71 to 80 age group. A little over half of the sample lived alone due to death of a spouse. Table 1 contains the description of the demographic variables. Although more than half of the elders did not work outside the home, the highest amount of schooling attained went up to 17 years. A little less than $30 \%$ of the elders did not have any schooling at all. More than $80 \%$ of the elders were permanent residents, and very few said they speak English fluently or fairly well. In fact, more than half did not speak English at all, but a few more of the people found understanding easier than speaking.

\section{TABLE 1}

DESCRIPTION OF SAMPLE OF KOREAN-AMERICAN ELDERS IN SUBSIDIZED HOUSING

Gender

Male $22 \%$

Female $78 \%$

Age (mean 73; range 60-89):

60-70

$28 \%$

71-80

$66 \%$

81-90

$6 \%$ 


\section{TABLE I}

(continued)

DESCRIPTION OF SAMPLE OF KOREAN-AMERICAN ELDERS IN SUBSIDIZED HOUSING

Marital Status

Married

$38 \%$

Widowed

$56 \%$

Divorced/Separated

$6 \%$

Reasons for Move to the U.S.

Job for self or spouse $\quad 4 \%$

Children

$96 \%$

Past Occupation

Housewife

$60 \%$

Business

$24 \%$

Farmer

$6 \%$

Teacher

$4 \%$

Cook

$2 \%$

Janitor

$2 \%$

Artist

$2 \%$

Level of Education (mean 6; range 0-17):

No Schooling

$28 \%$

8th Grade

$38 \%$

High School

$26 \%$

College Plus

$8 \%$

Residential Status

U.S. Citizen $\quad 16 \%$

Permanent Resident $\quad 84 \%$

Length of Stay in the U.S. (mean 13; range 4-23):

4-10

$30 \%$

11-15

$28 \%$

16-20

$38 \%$

$21-23$

$4 \%$

Length of Stay in the Portland Area (mean 12; range 4-23):

4-10

$42 \%$

$11-15$

$24 \%$

$16-20$

$30 \%$ 
TABLE I

(continued)

DESCRIPTION OF SAMPLE OF KOREAN-AMERICAN ELDERS IN SUBSIDIZED HOUSING

21-23

Have Children

Yes

No
$4 \%$

$100 \%$

$0 \%$

Have Lived with Child

Yes

$78 \%$

No

$22 \%$

Length of Stay with Children (mean 3; range 1-16):

1-5

6-10

$84 \%$

$13 \%$

11-16

$3 \%$

Length of Stay in Current Address (mean 7; range 1-15):

$1-5$

6-10

$38 \%$

$38 \%$

$11-15$

$26 \%$

Prior Place of Residence

Another Senior Housing $\quad 14 \%$

House/Apartment

$24 \%$

Children's House

$60 \%$

Other

$2 \%$

English Speaking Ability

Fluently

Fairly Well

$2 \%$

$4 \%$

A Little Bit

$34 \%$

Not At All

$60 \%$

English Comprehension Ability

Fluently

Fairly Well

$2 \%$

A Little Bit

$4 \%$

Not At All

$38 \%$

54 
Research Question One: What factors are involved in the decision of KoreanAmerican elders to move into subsidized housing?

As shown on Table 1, about one-third of the elders had lived in a regular house or apartment by themselves or with their spouse prior to the move to the current residence. Approximately two-thirds of the elders had previously lived with their children. For these elders, the main factors that influenced the elders to move away from their children are shown on Table 2. The most common reason for the move was to avoid an uncomfortable situation with the children. Whether the elders already felt a strain or anticipated trouble is not clear.

TABLE 2

FACTORS PROPELLING ELDERS TOWARD AN INDEPENDENT LIVING ARRANGEMENT

Factors

Comfort

Not Enough Room

Financial Burden on Children

Transportation

Social Life

Independence

Other
$32 \%$

$14 \%$

$14 \%$

$10 \%$

$10 \%$

$10 \%$

$10 \%$

When respondents were asked what made living with their children's family uncomfortable, the majority said being in the same household made them be more careful and that being alone was more comfortable. This indicated a preference for privacy. Since the second and third categories (not enough rooms and financial burden on children) are both related to children's financial strain, they can be 
combined to make a new category as children's financial strain (28\%). Two percent of the people who indicated transportation ( $10 \%$ of the sample) was the main reason for the move said they attended church every morning and could not possibly ask the children for a ride daily. This is related to independence- not having to rely on children for transportation. The other respondents said the children lived away from public transportation, so they moved to where they could easily catch a bus. The other $10 \%$ who indicated social life as the reason simply wanted to be close to where their friends already lived. Since a large proportion of the elders' need for transportation was to meet friends- whether it's at church, Korean Elders Association meetings or at the public housing, combining the transportation and social categories together makes $20 \%$ of the response.

When it came to the decision to move out to independent living arrangements, $80 \%$ of the elders reported that they had complete say in the decision. Fourteen percent said they had some say and $6 \%$ said they had no say, denoting that the children initiated the move. Having other Koreans in the same building was not a big decision factor for many of the elders. Seventy percent of the elders said they would have moved even if there were not any Koreans in the building.

When the elders were asked how their family reacted when they first decided to move out, $34 \%$ of the elders said the family thought it was a good idea, $36 \%$ thought it was fine, $26 \%$ thought it was not good, $4 \%$ thought it was a bad idea. However, after the elders have lived independently, $68 \%$ said the family now think it is good, $24 \%$ think it is fine, $6 \%$ think it is not good, and only $2 \%$ think it is bad. 
Figure 1 shows the parents' perception of how the children's view has changed favorably toward their parents living independently.

Research Question Two: Are Korean-American elders satisfied with living independently?

Hypothesis One: Korean-American elders are satisfied with their independent living arrangement. Based on the survey, $29 \%$ of the surveyed elders said they were very satisfied, and $42 \%$ said they were satisfied with the current living arrangement now compared to living with their children. Sixteen percent of the elders were more dissatisfied, and $2 \%$ were very dissatisfied living independently. Eleven percent said that it was about the same. Figure 2 shows the distribution of level of satisfaction. Hypothesis one is supported by this finding. A majority of the elders were satisfied with the independent living arrangement.

Research Question Three: What is quality of the relationship between KoreanAmerican elders and their children?

Hypothesis Two: Korean-American elders in independent residences do not hold a positive view of their children's values and of their intergenerational relationship. The elders were satisfied with the decision to live independently, and they perceived a positive relationship with their children. The mean in the relations with children score is 2.73 in the 1 to 4 range (See Figure 3). There were a few who 


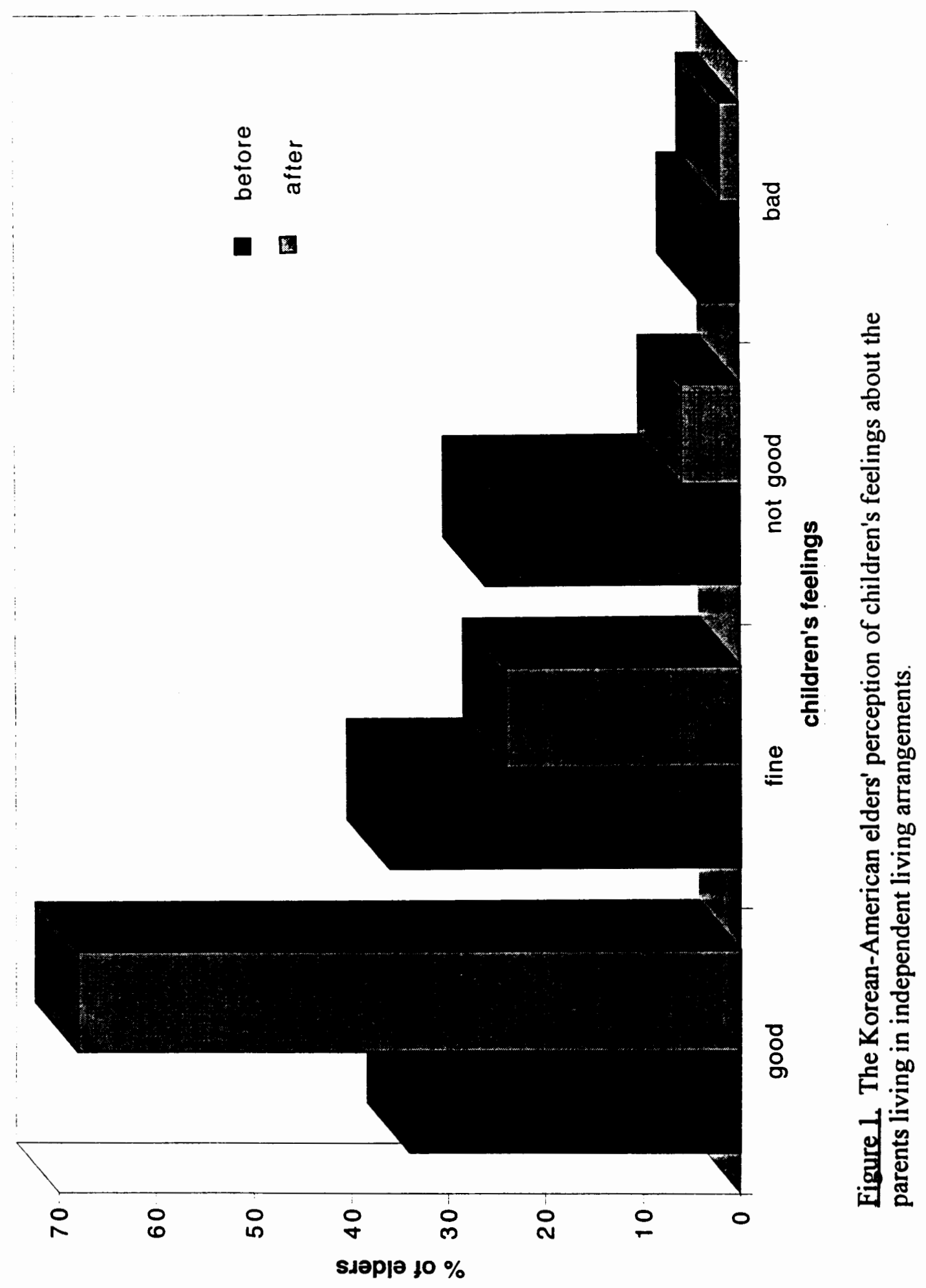




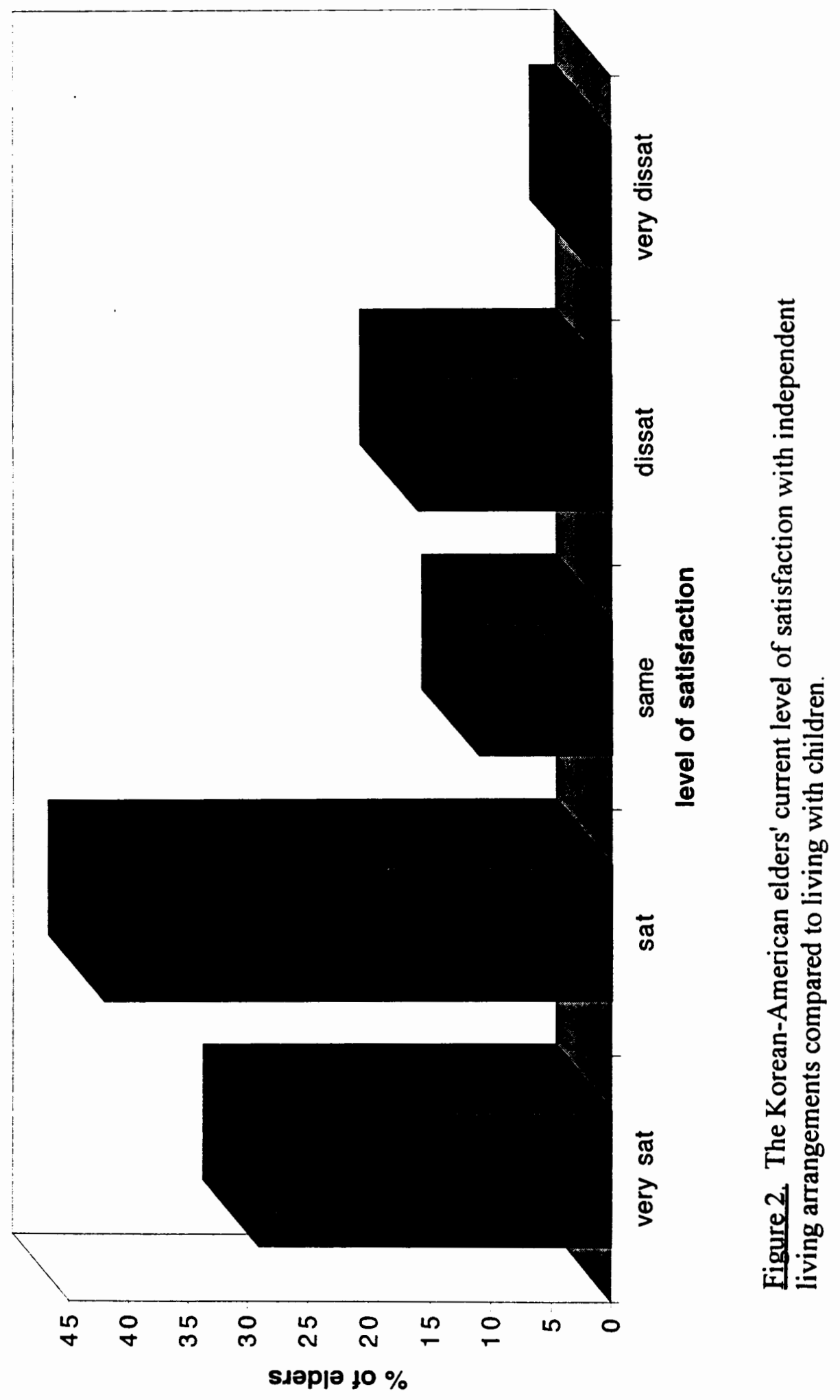




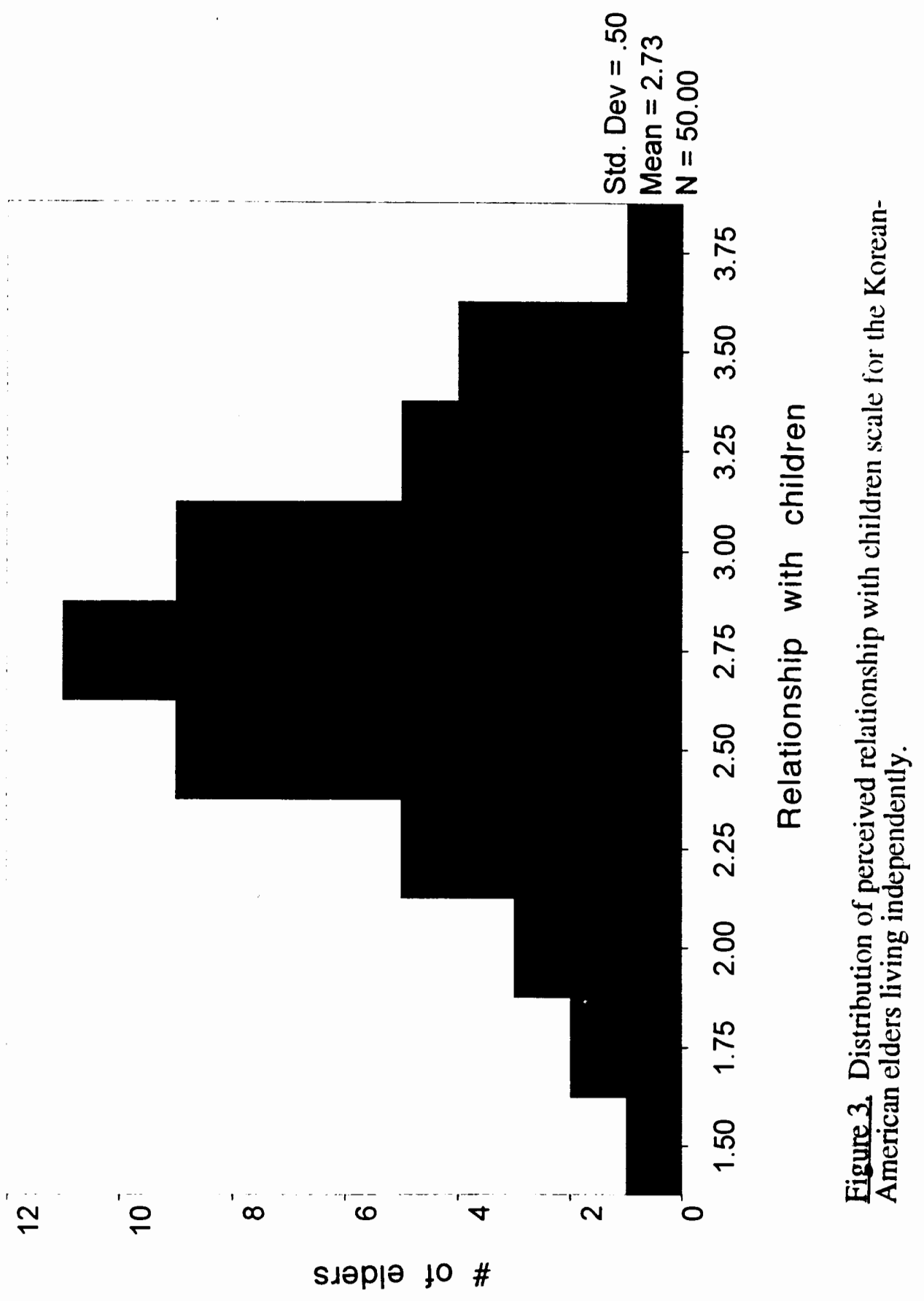


felt extremely positive about the children's values and how they were treated, but the majority were in the middle ground with a bit of shift in the positive direction. Two of the positive questions that $70 \%$ or more respondents strongly agreed with were that the children have a good value system and that the elders were satisfied with the way the children are raising their kids. One negative question that most of the respondents strongly agreed with was that they had very little desire to influence children's lifestyles, meaning they do not want to be actively involved in the children's life. Table 3 shows the respondents' responses to the relationship questions. The positive overall score indicates that the elders perceived a positive relationship with their children. This supports hypothesis two, although the positive feeling was not a strong one but more of an acceptance of the way things were.

Hypothesis Three: Korean-American elders would prefer not to live with their children. Seventy percent of the respondents in this study said they would not live with their children in the future, $12 \%$ said they would, $18 \%$ said they would only if they have to. This supports hypothesis three. When the respondents were asked whether they have to help out the children if they were to live with them in the future, only $28 \%$ of the respondents said they would have to help with babysitting if they were to live with their children, and $8 \%$ said they would help with the housework. Sixty-four percent said they would not have to do anything. $\underline{\text { Research Question Four: To what extent are Korean-American elders living in }}$ $\underline{\text { subsidized housing able to function independently? }}$ 


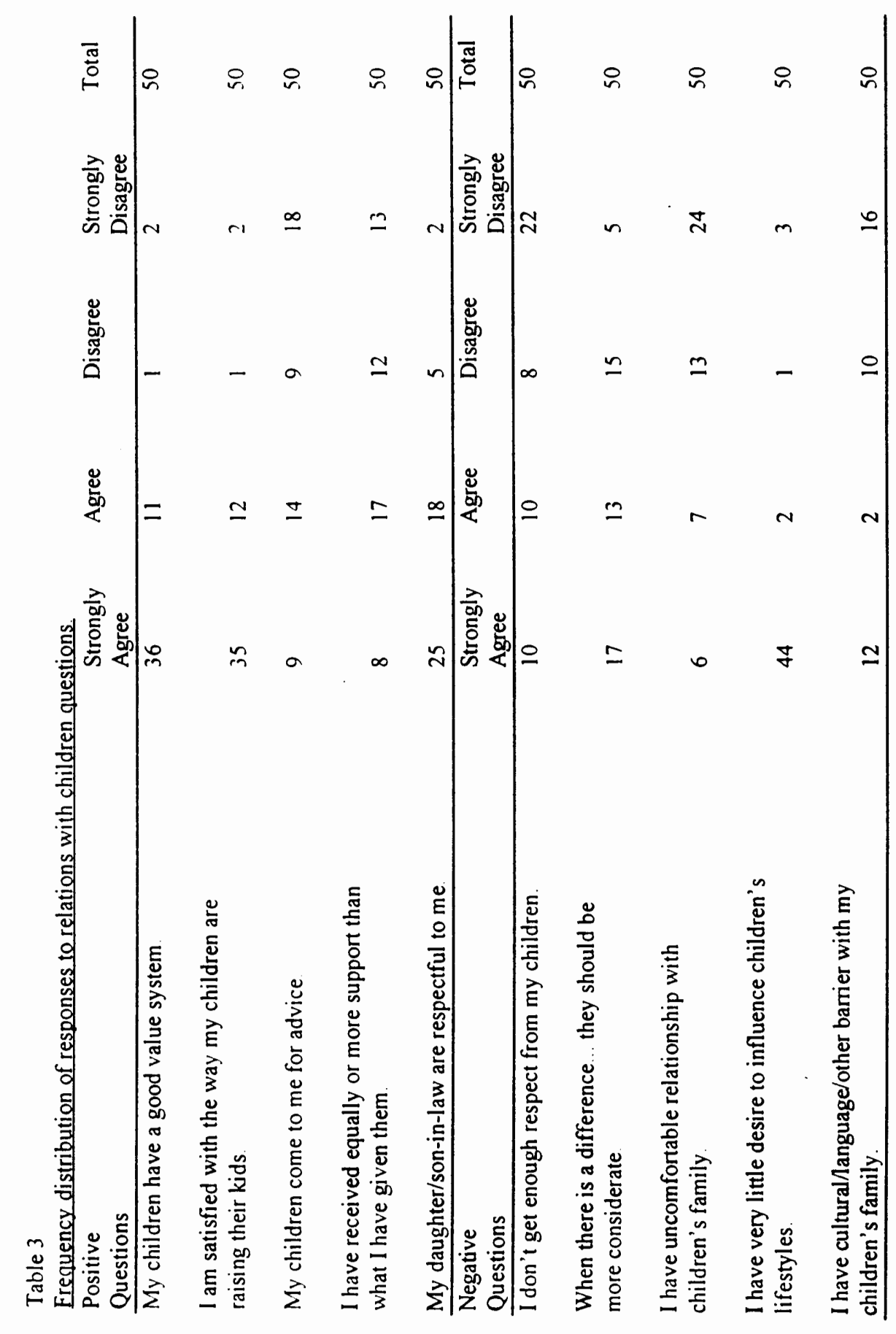


Hypothesis Four: The Korean-American elders in independent living are

dependent on others for carrying out some of their Instrumental Activities of Daily

Living (IADL). In contrast to the hypothesis, the Korean-American elders who are living on their own were independent on IADL's. In terms of handling cooking, laundry, housework, getting medication and managing finances, more than $70 \%$ of the surveyed elders were shown to take care of the above tasks by themselves on a regular basis. Less than $22 \%$ of the elders were not doing the tasks by themselves, and a few were doing the tasks by themselves on irregular basis (See Table 4). Accounting for the fact that $38 \%$ of the sample population was married and $22 \%$ of the population was male, it is likely that a substantial portion of the tasks that were not getting done by the respondent were still taken care of within the household by their spouses since Korean males are not accustomed to cooking and housecleaning in general. Although a few respondents shared that their spouse took care of cooking and cleaning for them, the question of whether the spouse actually did the household work for the respondent was not consistently asked of all the male respondents. Consequently, it can be concluded that at least three-fourths of the surveyed Korean elders handled the daily activities without getting help from the outside.

Hypothesis Five: Those who are more fluent in English will be more independent on carrying out IADLs. It is worthwhile to point out that more than $90 \%$ of the elders said that they were not able to speak or understand English well, yet more than $80 \%$ of them were sufficiently handling the instrumental daily activities by themselves. It is clear that Korean-American elders in the independent 
living arrangement are extremely self sufficient regardless of their ability to speak English. There was no significant correlation between English fluency and ability to carry out IADLs. One may speculate that such a high self-sufficient answer was possible due to counseling and encouragement among the Korean elders in the apartment complex. However, this logical speculation is probably wrong because $70 \%$ of the sample answered that they would have still moved into an apartment complex even if there were no Koreans.

TABLE 4

\section{PERCENTAGE OF ELDERS WHO CAN CARRY OUT INSTRUMENTAL ACTIVITIES OF DAILY LIVING BY THEMSELVES}

\begin{tabular}{llcl}
\hline Activities & $\begin{array}{l}\text { Yes } \\
\%\end{array}$ & $\begin{array}{c}\text { Sometimes } \\
\%\end{array}$ & $\begin{array}{c}\text { No } \\
\%\end{array}$ \\
\hline Laundry & & & \\
Housework & 78 & 4 & 18 \\
Cook & 78 & 12 & 10 \\
Get Medication & 76 & 2 & 22 \\
Manage Finances & 72 & 12 & 16 \\
& 86 & 4 & 10 \\
Average & & & 15.2 \\
\hline
\end{tabular}

Hypothesis Six: The Korean-American elders are socially dependent on their children, rather than relying on other resources such as friends, neighbors, formal aids, their spouse, or themselves. Prior to asking the respondents who they would call on for help in different situations, the respondents were asked who they thought was most helpful in providing for the needs of senior citizens. Forty-two percent of 
the elders said children, while $46 \%$ said friends and $12 \%$ said government. Of the $46 \%$ who picked friends as being most helpful, $30 \%$ specifically named friends from church or a member of the clergy. This result is contrary to the hypothesis. However, the findings regarding who the elders would call when they are in need show that the adult children are an important source of support for the Korean elders in independent living arrangements. As hypothesized, the elders identified children as most helpful in the specific questions, but the respondents said that friends were most helpful in the general question. Table 5 contains the information on the elders' social network. More than $50 \%$ of the elders said that they would call their children when they are sick, when they need to consult on important matters, and when they need to move. Averaged across the ten types of assistance, about $30 \%$ of the elders would call the children when in need.

Close to $30 \%$ of the elders said they would not turn to anyone and would go without getting the need filled if it is not something that they can handle themselves. If they have a need for minor items such as eggs, spices or something small, twothirds of the elders would go without it since it is not crucial. About $70 \%$ of the elders would not turn to anyone if they needed money. The only other source the elders named was children when in need of money. Forty-four percent of the elders would not talk to anyone when they feel bad or worried about something. Of these $44 \%$ of the people, some said they did not want to talk to their children because they did not want the children to worry. If the problem was with the children, the elders 


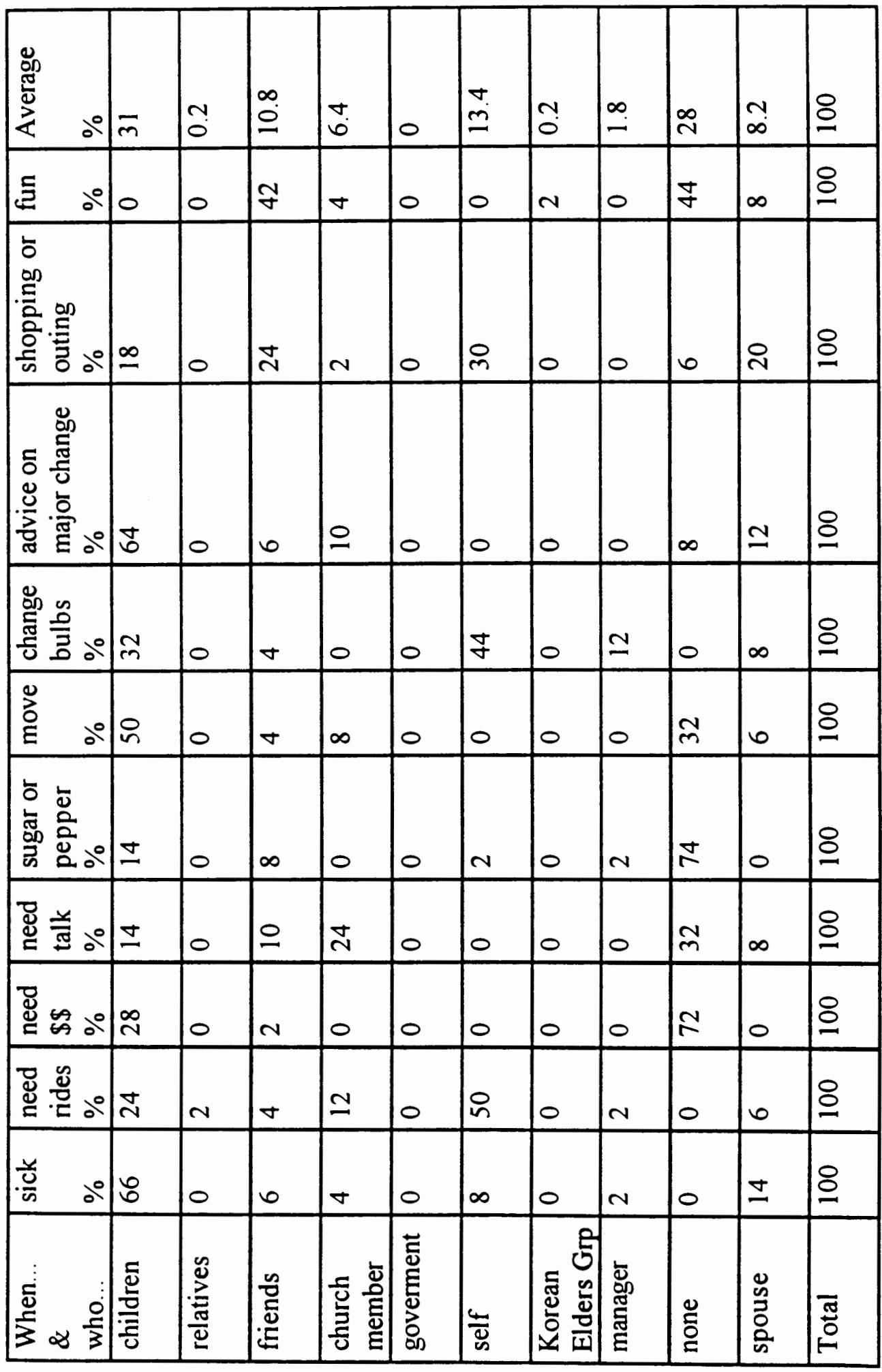


did not want to talk to anyone because people would think badly of their children. About $10 \%$ more elders would talk to a pastor or someone from church about what was pressing on their hearts than turn to their children. For the items that the elders can manage themselves, many of the elders said they would take care of it themselves. For instance, if there was a need for transportation, $50 \%$ of the respondents answered that they would either walk or take a bus. Changing a light bulb and taking care of simple maintenance was another thing that many of the elders said they would do by themselves. Thirty percent of the respondents would rather go shopping or on an outing by themselves unless they have a spouse. An interesting finding is that $44 \%$ of the elders said they would not do anything fun with anyone. The other $42 \%$ said they would do something fun with friends and neighbors, $8 \%$ with their spouse, but none with their children. The average frequency of seeing friends was daily while the average frequency of seeing the children was weekly. Most of the friends lived in the same neighborhood while most of the children lived in the same city.

Research Question Five: How is the self-esteem of the Korean-American elders living independently? How does their relationship with their children influence self$\underline{\text { esteem? How do demographic variables affect self-esteem? }}$

Hypothesis Seven: Korean-American elders living in subsidized housing do not have a high self-esteem. Figure 4 shows that the mean of these elders' self-esteem score to be 3.11 in the 1 to 4 range, indicating that their self acceptance level is 


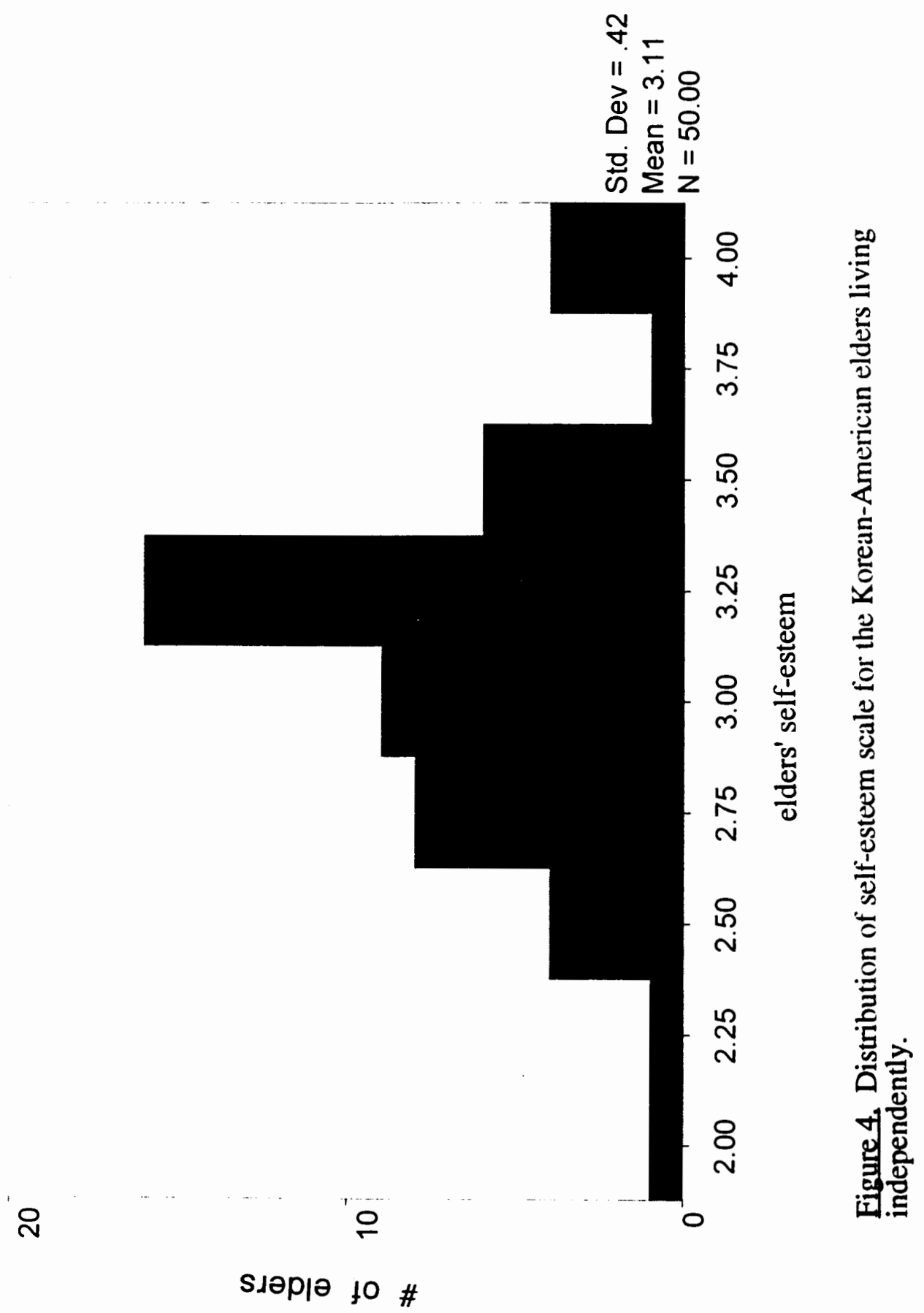


definitely on the high side. This does not support the hypothesis that these elders do not have a positive self-esteem. The mean of self-esteem is fairly close to the mean of the relationship with children score (3.11 and 2.73); the correlation coefficient for the two sets of data is $0.29(\mathrm{p}<0.05)$. There is a positive correlation between how the elders perceive their relationship with their children and how they view themselves. Moreover, when studying the data distribution between the two categories, the elders who scored low on the Relationship with Children scale (six respondents) also scored extremely low on self-esteem.

Hypothesis Eight: The length of stay in the United States and level of education will be positively related, while age will be negatively related, to high selfesteem. The correlation coefficient between length of stay in the United States and self-esteem in this study did not show a significant relationship. This hypothesis was not supported by the analysis. The age and level of education for the elders did not correlate with their self-esteem either.

Research Question Six: What predicts the satisfaction of Korean-American elders with independent living?

Hypothesis Nine: The elder's perceived relationship with their children will be positively related to their satisfaction with living independently. There was no correlation between perceived relationship with children and the elders' satisfaction with living independently. 
Hypothesis Ten: The length of stay in the United States, gender, decision power, length of stay with children, reasons why they decided to move and desire to live with children in the future are significant predictors for satisfaction with independent living. The correlations between satisfaction with independent living and the possible predicting factors were as follows: length of stay in the United States $(r=-0.39, p<0.01)$, gender $(r=-33, p<0.05)$, length of stay with children $(\mathrm{r}=-0.67, \mathrm{p}<0.01)$, and desire to live with children in the future $(\mathrm{r}=0.42, \mathrm{p}=0.01)$. With the exception of decision power, the other factors were significant predictors of satisfaction with independent living. Korean-American elders who lived a shorter time in the United States, were male, who had a lived shorter time with their children, and who did not wish to live with their children in the future were more satisfied with independent living arrangements. Because length of stay in the U.S. and length of stay with children were significantly positively correlated $(r=0.40, p<0.05)$, a regression analysis was run with these two variables as independent variables and satisfaction with independent living as the dependent variable. With both variables in the equation, only length of stay with children significantly predicted satisfaction with independent living $\left(\beta=-0.61, \mathrm{p}<0.001 ; \mathrm{F}=15.61, \mathrm{p}<0.001, \mathrm{r}^{2}=0.43\right)$. 
Chapter Five

\section{Discussion and Conclusions}

This thesis aimed at understanding the dynamics involved in the transition of the Korean-American elders in their living arrangements. The difference between reality and ideology brought struggle for the elders, and they chose to be in an independent living arrangement. The fundamental question is how are the KoreanAmerican elders in independent living arrangements faring in the following categories: level of independence in carrying out daily activities, self-esteem, and relations with children.

In an attempt to understand how the Korean-American elders in independent living arrangements are doing, several important points have been found. (1) The elders moved out to find the comfort, independence, lessen the financial burden on the children, and be with their friends. (2) The majority of the elders decided on their own to move out. (3) After seeing the elderly parents live independently, the elders think that the children see the situation favorably. (4) The elders are primarily satisfied with the current situation and for the most part do not want to live with the children in the future. They also would not feel they need to help the children around the house even if they were to live with them. (5) The length of stay in the United States, gender, length of stay with children, and desire to live with children in the future are significant predictors of satisfaction with independent living. (6) The elders hold a positive perception of their children's values and of the quality of their 
relationship with their children. There are a large number of elders who would not talk to anyone about what is bothering them if it is going to make their family look bad. (7) They also have high self-esteem. (8) Most of the elders carry out instrumental activities of daily living on their own. (9) Children are the number one helping network that the elders turn to when in need of specific types of help aside from trying to do things on their own.

Factors involved in the decision to move. Considering the expectation to be served by the children which is embedded in the traditional teaching of the Confucianism, the elders cannot totally abandon the traditional upbringing in their background, even though they accept the difference in values between themselves and their children. The main reasoning for wanting to move out was for a higher comfort level. By not seeing the children in daily action, the elders can be more nonchalant as to the "how" the children carry out their lives and how they relate to the elders. The role of the elder becomes more clear when they are in the independent living arrangement. The elders do not expect as much from the children and vice versa for the children who understand that the extra help they get is a "bonus" rather than a basic package that comes with living in the same household. The choice of independent living promotes an empowerment and striving for independence mentality rather than an expectation of being served.

Decision making power is what the Korean-American elders wish they could get from the children, and many times it is not easy for the children to reserve that power for the elders who are unfamiliar with the American ways (Kim et al, 1991). 
But for the respondents, they had the decision making power when they moved out, indicating that it was a voluntary move of most of the elders. In comparison to the negative effect of involuntary move that is known for nursing home residents, the voluntary move for the elders in this study should have a positive effect on them.

Kim et al. (1991) also mentioned that the children were ashamed to let their parents move out because it is an indication that they did not take care of them. Since some time has passed since the literature was written, perhaps the idea of the elders moving out has become more accepted by the Korean population. The elderly parents in this study perceive that their children's view of independent living has changed more favorably after seeing the parents live independently.

Satisfaction with living independently. The literature shows that the elders who are currently living with their children wish to move out but whether the elders in independent living arrangement wish to live with their children in the future is not known. Although the finding of $71 \%$ who are currently satisfacted is not as high as shown by Han's study (90\%), this study supports the research literature and the hypothesis that Korean-American elders are satisfied with their living arrangement compared to living with their children. Moreover, majority of the respondents indicated that they do not want to live with their children in the future. The literature showed that the elders when living with their children had to help out with housework, babysitting or managing the children's business (Kang \& Kang, 1983; Kim et al, 1991). But the respondents said they would not have to give domestic help even if they were to live with children in the future. Perhaps the elders feel that 
they would not live with the children unless their physical independence gives out, in which case they would not be capable of helping around the house anyway.

For those elders who are living with the children and are struggling with the idea of moving away from the children, it might be an encouragement to know that the majority of the elders who are already independent find it satisfying. Many elders probably already know this by talking to friends who are already living independently. However, even if the elders currently living with children want to move out, the new legislation removing welfare eligibility for permanent residents may make it difficult for many. Although most of the surveyed elders are satisfied with independent living, since most of them do not have the U.S. citizenship, they may have to move back in with their children. While interviewing, some of the elders had voiced their concerns and worries that the funds for the subsidized housing programs might be cut in the future. For many Korean-American elders, the independent living arrangement that is possible through public assistance is an essential provision for coping with cultural and family structural changes. They have desired the independence and they are satisfied with it so they intend to keep the situation if possible. Many of the elders said that they were taking citizenship test preparation classes offered through the Korean Elders Association program.

Considering that the majority of the elders came to America to keep family ties with their children, it is ironical to learn that these same elders are satisfied living independently away from their children. One may easily attribute assimilation to American lifestyle as the explanation behind this irony, in which case the elders who 
have lived in the U.S. longer should find more satisfaction in independent living arrangements.. However, unlike the expectation, the predictors of satisfaction with independent living arrangement indicate the contrary. The elders who are more likely to be satisfied with the independent living arrangement are males, those who have not been in the United States long, have not lived with children long and do not have a desire to live with children in the future.

The puzzling question of why the Korean-American elders who have been in the U.S. a longer time are finding less satisfaction living independently could possibly be answered by assuming that these elders do not adhere to assimilation theory and they hold on to traditional Korean ways regardless of length of stay in the U.S.. The concept of the traditional Korean way is probably different between the older and recent Korean immigrants. Youn \& Song (1991) have stated that the trend has been changing to a modified extended family in Korea, but the older immigrants may expect the Korean way to be how it was when they left Korea years ago. The more recent immigrants may have had a chance to encounter the changes similar to Westernization taking place in Korea, and be less likely to expect the traditional ways than the older immigrants.

However, the regression analysis indicates that the critical variable is how long the elders have lived with children rather than how long they have lived in the U.S. when determining the satisfaction in independent living arrangements. Perhaps the elders who had lived longer with their children became more accustomed to the 
dependent living arrangement, and have a harder time finding satisfaction in independent living arrangements.

Relationship with children. The elders perceive a positive and active relationship with their children.. Possible reasons for discontent could lie in the generational gap widened by different levels of assimilation between the elders and the children into American lifestyle and demands. Although the positive feeling is not a strong one, it is indicative of a feeling of acceptance of the difference. The elders do not necessarily feel that the children are giving back what the elders gave the children in the past, nor that the children give the elders much chance to share their wisdom by giving advice. However, the elders seem to know that the children's value system and how they do things are different due to generational and cultural gaps. In fact, the majority of the elders do not think that the children's values are bad at all. The literature showed that the children would like to fulfill filial piety but that there are obstacles (Kang \& Kang, 1983; Kim et al, 1991). Perhaps the elders understand the children's dilemma to some degree. The elders are putting in their share of effort to adapt to change by deciding to live independently. As indicated by the positive perception of their relationship, the understanding of their differences has been established.

Functioning independently. The elders are quite capable and are willing to tackle daily tasks on their own as they live in independent living arrangements. Although the majority of the elders are in their seventies, they seem quite capable of handling IADLs. The logical assumption is that it is probably the capable elders who 
have chosen to move out in the first place. The length of stay in independent living arrangements ranges from one to fifteen years, but the mean is 7 years. As more of the elders who are now in their seventies reach their eighties, handling the IADLs on their own will become more difficult. Fluency in English does not seem to affect their functioning ability even when in need of interaction with Americans. The elders keep a very independent mentality. Many of the elders would not turn to anyone if it is not something that they can handle by themselves.

$\underline{\text { Social network. }}$ Youn \& Song (1991) noted that adult children are an important source of support for the Korean elders. As the social network results showed, the elders depend on their children more than anyone for emergency situations or when in need of discussion to make important decisions. In theory, the elders said their friends are most helpful in providing for the needs of senior citizens, but when specific scenarios were given, more than half of the elders said they would call their children to get their needs filled.

Self-Esteem. Week and Cuellar (1983) and Moon and Pearl (1991) had found length of stay in the United States to have an inverse relationship with feelings of isolation. According to this, the length of stay in the United States and self-esteem should have a positive relationship. However, the results from this study did not find any correlation between length of stay in the United States and self-esteem. The only significant correlate of self-esteem is relations with children, so the elders with a high level of self-esteem are more likely to have a high level of acceptance of their children. 
The Korean-American elders faced cultural change as well as changes in family dynamics and living structure, but a positive attitude is reflected in their high self-esteem score. The average self-esteem score tends to be shifted to the high side although the scores are not in the extremes. The scores do not necessarily indicate a full adjustment or assimilation but that the elders are content with how they are or how they have handled things. The literature shows that the primary reason for the elders to come to the United States is to keep their family ties. More than $95 \%$ of the elders said that they decided to come to United States because of their children. But meeting the traditional expectations of filial piety is a big challenge in America, and the Korean-American elders not only acknowledged this fact but found a way take on the challenge. The elders were torn between ideology and reality (Kang \& Kang, 1983) in the past, but these elders found a remedy to the problem. The elders living independently felt good about molding their own reality. The quality of life was good as indicated by their high self-esteem scores.

One point of caution is to not encourage independent living for those elders who have a high potential to be dissatisfied or be alienated by living independently. There were those elders who did not choose on their own to move out (who either indicated that they did not make the decision to move out or those who indicated that they moved to lessen children's financial burden), who are not satisfied with independent living, who want to live with their children, and who do not want to do any fun activities with anyone. The tendency for many Korean elders to not talk about their feelings with anyone may make the elders prone to illness. If there were 
a way to monitor and promote programs for a high quality of life for those elders in independent living arrangements, more attention should be given to those who indicated that they would not talk to pastors or children about the burden on their hearts.

Strengths and Limitations of the Study

Due to lack of prior studies on Korean-American elders living independently, there has not been much understanding of the well-being of these elders who underwent changes in family structure and living arrangements. This study covered the general well-being of the Korean-American elders living independently by looking at the factors involved in the decision to move, the elders' satisfaction with living independently, their perceived relationship with the children, physical independence, social networks and self-esteem. The results of the study provided useful information on understanding how the Korean-American elders are doing in general in the independent living arrangements. However, this study was limited by a small number in the sample without a comparison group. Nonetheless, this study can be used as a base from which more in-depth studies on specific topics can be built in the future since this study covered a wide range of topics in general.

\section{Future Research}

In my future research I wish to extend my work to exploring a larger group of Korean-American elders in independent living arrangements. The quality of life for these elders will continue to be an important issue to study and understand. Also, the particular issue of loneliness and feelings of alienation could be given more 
attention in addition to assessing their self-esteem. Another interesting study to pursue would be on the elders' expectation of filial piety and how they feel their children are fulfilling the expectation. A new method for a qualitative study would be to formulate open-ended questions in a discussion format in studying the elders' values and do a comparison with their children. Studying the children's values, their perspective on filial piety, and their role in the helping network for the elders would greatly enhance the understanding of what resources the elders have in sustaining their quality of life in independent living arrangements. 
References

Abeles, R.P. (1994). Aging \& Quality of Life. New York: Springer Publishing Company.

Baum, M. \& Baum, R. (1980). Growing Old: A Societal Perspective. Englewood Cliffs, N.J.: Prentice-Hall, Inc.

Brown, A.S. (1990). The Social Processes of Aging \& Old Age. Englewood Cliffs, New Jersey: Prentice-Hall, Inc.

Chung, C. (1995). A Korean Confucian Encounter with the Modern World.

Berkeley, California: The Regents of the University of California.

Davis-Friedmann, D. (1983). Long Lives: Chinese Elderly and the Communist

Revolution. Cambridge, Mass.: Harvard University Press.

Fischer, D.H. (1978). Growing Old in America. New York: Oxford University Press.

Goode, W. (1963). World Revolution and Family Patterns. Glencoe, Ill.: Free Press.

Han, M. (1986). Social Interaction and Life Satisfaction Among the Korean-

American Elderly, Unpublished Dissertation, St. Louis, Missouri: St. Louis

University.

Hong, S. \& Keith, P. (1992). The Status of the Aged in Korea: Are the Modern More Advantaged? The Gerontologist, 32, 197-202.

Kang, T. \& Kang, G. (1983). Adjustment Patterns of the Korean-American Elderly: Case Studies of Ideal Types. Journal of Minority Aging, 8, 47-55.

Kiefer, C. W. et al. (1985). Adjustment Problems of Korean American Elderly. The Gerontologist, 25, 477-482.

Kim, K., Kim, S. \& Hurh, W. (1991). Filial Piety and Intergenerational Relationship in Korean Immigrant Families. International Journal of Aging and Human Development, 33, 233-245.

Koh, J. \& Bell, W. (1987). Korean Elders in the United States: Intergenerational Relations and Living Arrangements. The Gerontologist, 27, 66-71.

Koo, H. (1981). Korean Immigration to the United States: its Demographic Patterns and Social Implications for Both Societies. Honolulu, Hawaii: East-West Center. 
Laslett, P. \& Furstenberg (1977). Societal Development and Aging. In R. Binstock $\&$ E. Shanas (Eds.), Handbook of Aging and the Social Sciences. (pp.87-116). New York: Van Nostrand Reinhold.

Leslie, G. \& Korman, S. (1985). The Family in Social Context. New York: Oxford University Press.

McPherson, B.D. (1983). Aging as a Social Process: An Introduction to Individual and Population Aging. Toronto: Butterworths.

Moon J. \& Pearl, J. (1991). Alienation of Elderly Korean-American Immigrants as Related to Place of Residence, Gender, Age, Years of Education, Time in the U.S., Living with or without Children, and Living with or without a Spouse. International Journal of Aging and Human Development, 34, 109-124.

Park, J. \& Lim, C. (1983). Research on the Living Condition and Consciousness for the Aged in Korea. Seoul, Korea: Korean Institute of Gerontology.

Quinn, W.H., Hughston, G.A. (1984). Independent Aging: Family and Social System Perspectives. Rockville, Maryland: An Aspen Publication.

Rosenberg, M. (1965). Society and the Adolescent Self-Image. Princeton, New Jersey: Princeton University Press.

Stokes, G. (1992). On Being Old: the Psychology of Late Life. Bristol, PA: The Falmer Press.

Sung, K. T. (1992). Motivations for Parent Care: the Case of Filial Children in Korea. International Journal of Aging and Human Development, 34, 109-124.

Sung, K. T. (1995). Measures and Dimensions of Filial Piety in Korea. The Gerontologist, 35, 240-247.

The U.S. Bureau of the Census. (1991). Census and You, 26, 3.

Weeks, J. R. \& Cuellar, J. B. (1983). Isolation of Older Persons: The Influence of Immigration and Length of Residence. Research on Aging, 5, 369-387.

Youn, G. \& Song, D. (1991). Aging Koreans' Perceived Conflicts in Relationships with their Offspring as a Function of Age, Gender, Cohabitation Status, and Marital Status. Journal of Social Psychology, 132, 299-305. 


\section{APPENDIX A: Questionnaire Used in English}

I.D.\#:

Date:

\section{A. Background}

1. Sex of the respondent (observe and check the appropriate answer)
1) Male

2) Female

2. When were you born?

Month Day Year

3. Are you?
1) Married
2) Widowed
3) Divorced/Separated
4)Other

4. When (in what year) did you come to the United States?

Year. Month

5. What was the primary reason for deciding to come to the United States?
1) Job for self or spouse
2) Children
3) Other specify

6. What was your occupation?

(Describe primary occupation, including housewife)

7. How many years of schooling did you complete?
Years of elementary
Total years
H.S. College

8. What is your residential status?
1) U.S. citizen
2) Permanent Residence
3) Other

9. When (in what year) did you come to Portland area? Year Month

10. When (in what year) did you move to this address? Year Month

11. Do you have any children?
1) Yes
2) No (Skip to 14) 
12. Have you ever lived with your children?
1) Yes
2) No (Skip to 14)
How long ago?
For how long? 13. When you compare your current living situation to when you were living with your children,
how satisfied are you now?

a) very dissatisfied b) dissatisfied c)same d)satisfied e) very satisfied

14. Where did you live before you moved to this place?

1) In another senior housing apartment

2) In a house/apartment (by oneself or with spouse)

3) In one of children's houses

4) Other specify

15. What influenced you to move here?

16. Even if there weren't any Koreans in this apartment complex, would you have moved here?
1) Yes

2) No

17. How much say did you have in your decision to move here?
1) Complete say
Explain:
2)Some say
3) None

18. How did your family react when you first decided to move here?

19. How do you think they feel about it now?

20. Who lives with you? (Name \& Relation)

B. Instrumental Activities of Daily Living (IADL)

(Now I'd like to ask you about some of the activities of daily living, things that we all need to do as a part of our daily lives. I'd like to know if you can do these activities without any help at all, or if you need some help to do them, or if you can't
do them at all.)

21. Do you drive?
1) Yes
2) $\mathrm{No}$

Could you? By self W/help Not at all 
22. Do you do your own laundry?
1) Yes
2) Sometimes
3) No

Could you? By self W/help Not at all

23. Do you do your own housework?
1) Yes
2) Sometimes
3) No Could you? By self W/help Not at all

24. Do you cook for yourself?

1) Yes

2) Sometimes

3) No Could you? By self W/help Not at all

25. Do you get your own medication?
1) Yes
2) Sometimes
3) No
4) Not applicable
Could you? By self W/help Not at all

26. Are you managing your own money?
1) Yes
2) Sometimes
3) $\mathrm{No}$ Could you? By self W/help Not at all

27. How well do you understand English when the manager, neighbor, or others speak to you?
1) Fluently
2) Moderately well
3) About half
4) Almost not at all
5) Not at all

28. How well do you think you can express yourself in English?
1) Fluently
2) Moderately weil
3) About half
4) Almost not at all
5) Not at all 
C. Social Services

29. Who do you think is most helpful in providing for the needs of senior citizens? Please rank top three:

1) Senior's children

2) Other relatives

3) Friend or neighbors

4) Clergy or church

5) Government

6) Individual senior or couple

7) Korean Elders Association

8) Other specify

9) Not sure/don't know

D. Informal social support networks.

(Now, I'd like to ask you about your family, friends, relatives, and neighbors.)

30. Who would you call?

a. If you are sick

b. If you needed a ride

c. If you needed a loan

d. If you were very upset

e. If you needed to borrow sugar or hot-pepper

f. To move furnitures

g. To change lightbulbs

h. To get advice on major change like moving to a different apt

i. Who do you go with for shopping, for a walk, or to a restaurant

j. Who do you get together to play games or talk about the current events 
31.

Name

Sex

Age

Location Relationship Frequency

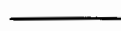
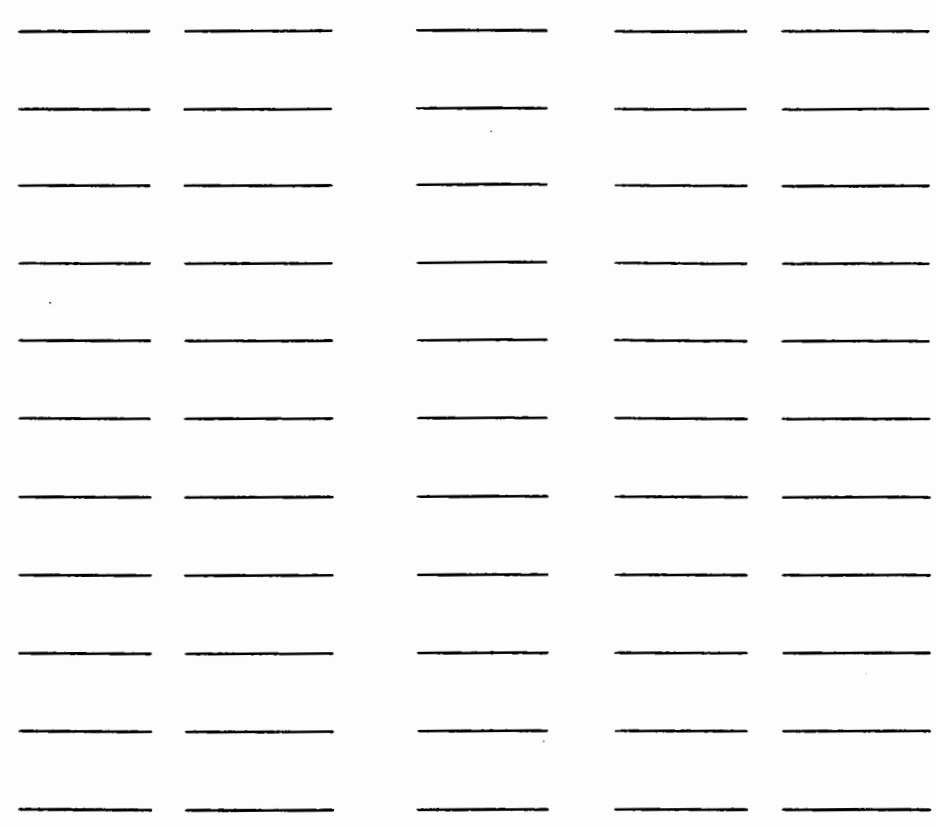

1) Same household

1) More than 1 a week

2) Same neighborhood

2) Once a week

3) Same city

3) 2-3 a month

4) Same state

4) 6-12 a year

5) Other state

5) Once a year

6) Abroad
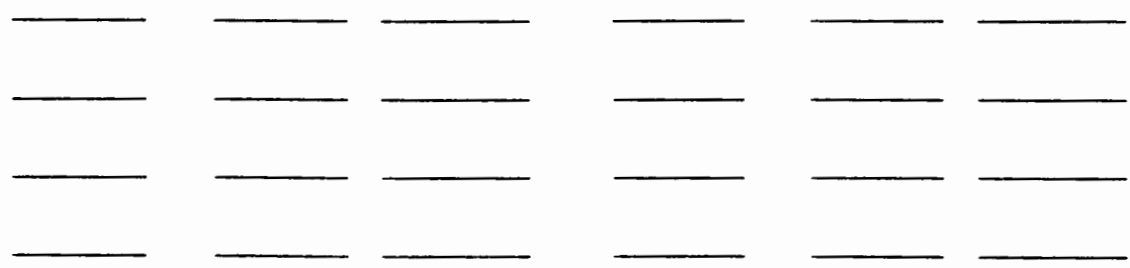
32. Would you like to live with your children sometime in the future?
1) Yes
2) Only if I have to
3) No

33. If you were living with your children's family, what kind of work or support would you have to do for the family?
1) Financial
2) Babysitting grandchildren
3) Housework
4) Other specify
5) None

34. I'd like to ask about your relations with the children.

(Please indicate whether you strongly agree, agree, disagree, or strongly disagree.)

1) My children have good value system. $\quad \begin{array}{llllll}1 & 2 & 3 & 4\end{array}$

2) I am satisfied with the way my children $\begin{array}{llllll}1 & 2 & 3 & 4\end{array}$ are raising their kids.

3) My children come to me for advice. $\quad \begin{array}{llllll}1 & 2 & 3 & 4\end{array}$

4) I don't get enough respect from my $\quad \begin{array}{lllll}1 & 2 & 3 & 4\end{array}$ children.

5) I have received equally or more support $\begin{array}{lllllll} & 1 & 2 & 3 & 4\end{array}$ from my children than what I have given them.

6) My daughter/son-in-law are respectful $1 \begin{array}{lllll}1 & 2 & 3 & 4\end{array}$ to me.

7) When there is a difference in opinion $\quad \begin{array}{lllll}1 & 2 & 3 & 4\end{array}$ between my children and I, the children should be more considerate of what I tell them.

8) I have uncomfortable relationship with $1 \begin{array}{lllll} & 1 & 2 & 3 & 4\end{array}$ my children's family.

9) I have very little desire to influence $\quad \begin{array}{llllll}1 & 2 & 3 & 4\end{array}$ children's lifestyles.

10) I have cultura/language/other barrier $\begin{array}{llllll}1 & 2 & 3 & 4\end{array}$ with my children's family 
35. Lastly, l'd like to ask you some questions about your feelings about yourself. For each statement that I read, please tell me whether you strongly agree, agree, disagree, or strongly disagree.

$\begin{array}{llll}1 & 2 & 3 & 4\end{array}$

1) I feel that I'm a person of worth, at least on an equal basis withothers.

2) I feel that I have a number of good qualities.

3) All in all, I am inclined to feel that I am a failure.

4) I am able to do things as well as most other people.

5) I feel I do not have much to be proud of.

6) I take a positive attitude toward myself.

7) On the whole, I am satisfied with myself. 4

8) I wish I could have more respect for myself.

9) I certainly feel useless at times.

10) At times I think I am no good at all.

$\begin{array}{llll}1 & 2 & 3 & 4 \\ 1 & 2 & 3 & 4 \\ 1 & 2 & 3 & 4 \\ 1 & 2 & 3 & 4 \\ 1 & 2 & 3 & 4 \\ 1 & 2 & 3 & 4 \\ 1 & 2 & 3 & 4 \\ 1 & 2 & 3 & 4 \\ 1 & 2 & 3 & 4 \\ 1 & 2 & 3 & 4\end{array}$




\section{APPENDIX B:}

Introduction Letter, Consent Form and Questionnaire Used in Korean

안녕하세요.

저는 포트랜드 주립대학원 졸업반 이 신옥 학생입니다.

이번에 저의 논문 주제는 미국에 사시는 한인 노인분들에 관해서

입니다. 저의 바램은 이 논문을 통하여 앞으로 우리 한국

노인분들께 보탬이 되었으면 합니다. 그래서 저의 논문에 필요한

몇가지 부분에 도움을 부탁드리려고 이렇게 편지를 드립니다.

곧 전화로 인사드리고 찾아 뵐테니, 잘 부탁드리겠습니다.

감사합니다. 
본인은 이 신옥 학생의 논문에 관하여 미리 연락을 받고 이에 1 시간 정도 인터뷰에 응하기로 했습니다. 이 논문의 내용은 빌딩관리상에 아무런 영향을 주지 않을 것이며, 본인의 사생활에 관하여도 무관하며 단지 논문 자료에 보탬이 될 수 있게 미리 설명을 받고 도움을 주고자 합니다.

서명
날짜- 
I. D. \#:

날 짜:

A. 인적 사항

1. 성별 (보고 쓰시오.)

1) 남

2) 여

2. 언제 태어나셨습니까? 년 느월 일

3. 지금 귀하는:
1) 결혼
2) 사별
3) 이혼/ 별거
4) 기타

4. 미국에 언제 (몇년도에) 오셨읍니까?

년 월

5. 미국에 오게된 주동기는 무엇입니까?
1) 직장
2) 자녀
3) 기타

6. 전직업이 무엇이었읍니까?

(주직업을 설명하시오. 예) 가정주부. )

7. 최종학벌.

국민학교 년, 중학교 년, 고등학교 년, 대학교 총 년. 
8. 지금 귀하는:
1) 미국 시민
2) 영주권자
3) 기타

9. 포트랜드에 언제 (몇년도에) 오셨읍니까?

년. 월

10. 현주소에는 언제 이사오셨읍니까? 년 월

11. 자녀가 있읍니까?
1) 예
2) 아니오

12. 자녀와 사신적이있읍니까?
1) 예 얼마전에 얼마동안
2) 아니오 (14번으로 가시오)

13. 가족들과 살때와 비교할때 지금 얼마나만족하십니까?
1) 무척 만족한다
2) 만족
3) 동둥
4) 불만족
5) 무척 불만족

14. 이곳에 이사오시기 전에 어디서 사셨옵니까?
1) 다른 노인 아파트
2) 집/아파트 (혼자 / 배우자와 합께)
3) 자녀의 집에서
4) 기타

15: 이곳에 오게된 동기는 무엇입니까? 
16. 이곳에 한국인이 없어도 이사오셨겠옵니까?

1) 예

2) 아니오

17. 이사오시는데 결정권이 얼마나 있었읍니까?

1) 완전히

2) 어느정도

3) 전혀 없었음

18. 이사오시기로 결정할때 가족돌이 어떻게 반응을 보였옵니까?

19. 지금은 어떻다고 생각하십니까?

20. 현재 누구와 살고 있읍니까?

(이름/관계)

B. 생활력.

21. 운전을 하십니까?

1) 예

2) 아니오 할수있읍니까? 혼자 도움받고 전혀

22. 빨래를 직접 하십니까?
1) 예
2) 가끔
3) 아니오 할수있읍니까? 혼자 도움받고 전혀

23. 청소를 직접 하십니까?
1) 예
2) 가끔
3) 아니오 할수있읍니까? 혼자 도움받고 전혀 
24. 식사준비볼 직접 하십니까?
1) 예
2) 가끔
3) 아니오
할수있읍니까? 혼자

도움받고

전혀

25. 약을 직접 사오십니까?
1) 예
2) 가끔
3) 아니오 할수있읍니까? 흔자 도움받고 전혀

26. 돈 관리를 직접 하십니까?
1) 예
2) 가끔
3) 아니오 할수있읍니까? 혼자 도음받고 전혀

27. 매니저나 이웃이나 다른 사람들의 영어를 얼마큼 이해하십니까?
1) 완전히
2) 어느정도
3) 반정도
4) 거짐못함
5) 전혀 못함

28. 영어로 의사표현을 얼마나 할수있읍니까?
1) 완전히
2) 어느정도
3) 반정도
4) 거짐못함
5) 전혀 못함 
C. 사회복지 혜택

29. 누가 노인들의 필요를 가장채워줍니까? (순서대로 3가지를 고르시오)
1) 노인들의 자녀
2) 친척
3) 친구 또는 이웃
4) 교회
5) 정부
6) 자신
7) 한인 노인회
8) 기타
9) 모르겠음

D. 가족과 친구 관계

30. 다음의 경우 누구에게 도움을 청합니까?
a. 아플 때
b. 차편이 필요할 때
c. 돈이 필요할 때
d. 속이 상할 때
e. 설탕이나 고추가루가 필요할때
f. 가구를 옮길때
g. 전구 다마를 끼울때
h. 중대한 상의롤 해야할때
i. 쇼핑이나 산보나 영화를 보고 싶을때
j. 게임을 하거나 시사문제를 토론하고 싶을때 


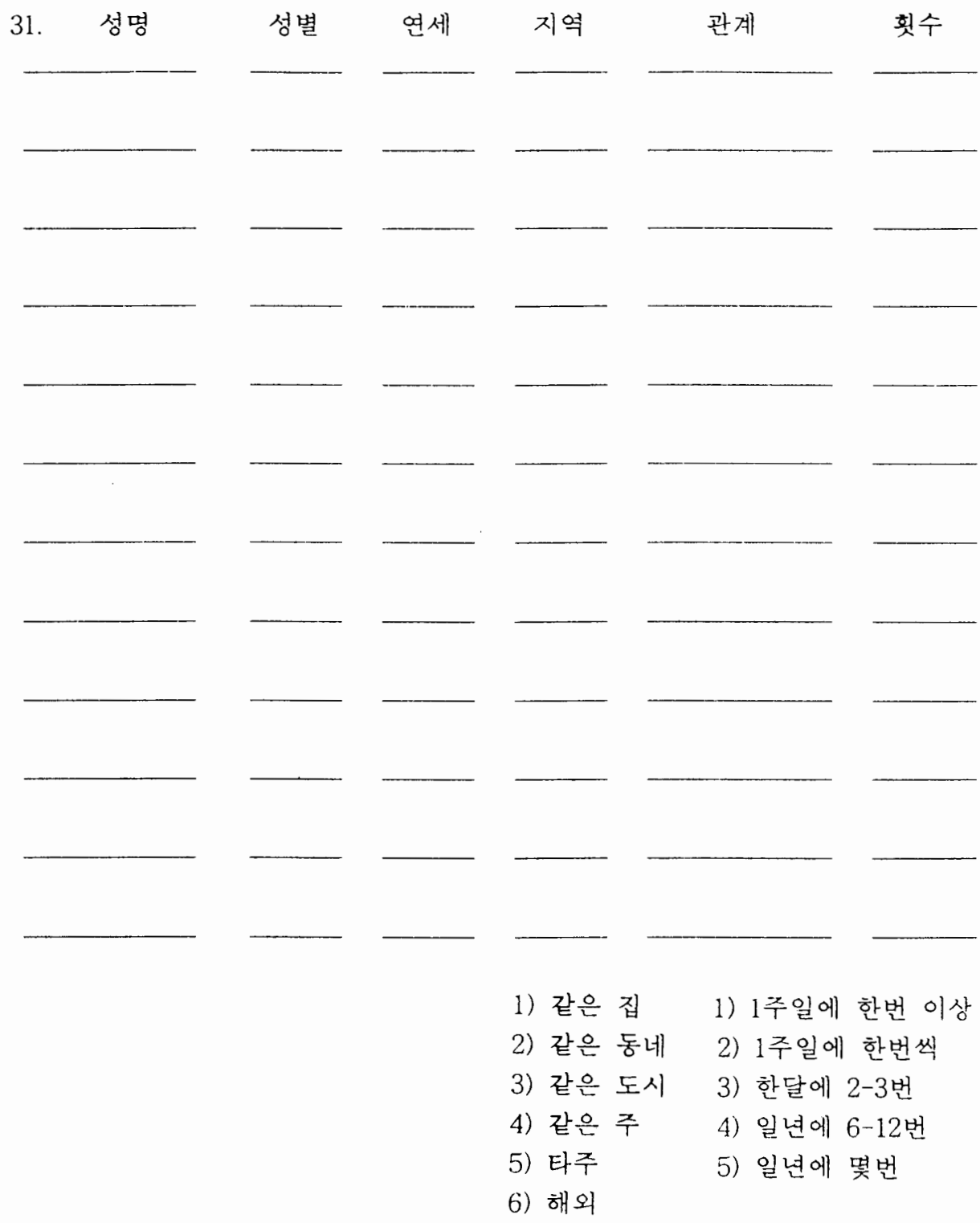
1) 같은 집
1) 1 주일에 한번 이상
2) 1 주일에 한번씩
3) 같은 도시
5) 타주
6) 해외
5) 일년에 몇번 
32. 훗날에 자녀와 사실 마음이 있읍니까?
1) 예
2) 꼭 필요하다면
3) 아니오

33. 만약에 자녀들과 살고있다면, 가족을 위해 어떤 일이나 도움을 주시고 있겠습니까?
1) 경제적인 도움
2) 손주들을 돌봄
3) 집안일
4) 기타
5) 전혀

34. 자녀관계에 대해서 여쭈어 보겠습니다.

(번호로 표시해 주십시오. 1-완전히 동의 2-동의 3-반대 4-완전히 반대)

1) 자녀들이 좋은 가치관을 가지고 있다.

2) 자녀들의 교육방침에 만족한다.

3) 자녀들이 나에게 도움이나 의견을 물으러 온다.

4) 자녀들이 나를 충분히 존중하지 않는다.

5) 내가 준 것만큼 혹은 그 이상 자녀들에게 받고 있다.

6) 사위나 며느리가 나를 존중한다.

7) 자녀들과 의견충돌이 있을 때, 그들이 나의 말을 더 들었으면 좋겠다.

8) 자녀들의 가족과 사이가 불편하다.

9) 자녀들의 생활방식에 참견할 마음이 없다.

10) 자녀들의 가족과 언어나 문화 둥의 벽을 느낀다. 
35. 마지막으로 자신에 대해 느끼는 대로 말해 주십시오.

(번호로 표시해 주십시오. 1-완전히 동의 2-동의 3-반대 4-완전히 반대)

1) 나는 다른 이들과 동둥하다고 생각한다.

2) 나에게 줗은 면돌이 있다고 느낀다.

3) 대체적으로 나는 실패자라고 느낀다.

4) 다른 이둘이 하는 것은 나도 할 수 있다.

5) 나는 자랑거리가 별로 없다고 생각한다.

6) 나는 나자신에 대해 긍정적으로 생각한다.

7) 대체적으로 나는 내 자신에 만족한다.

8) 내자신이 나를 더 존중하기를 바란다.

9) 나는 때로는 필요 없는 존재라고 느낀다.

10) 때로는 나는 좋은 면이 하나도 없다고 생각한다. 


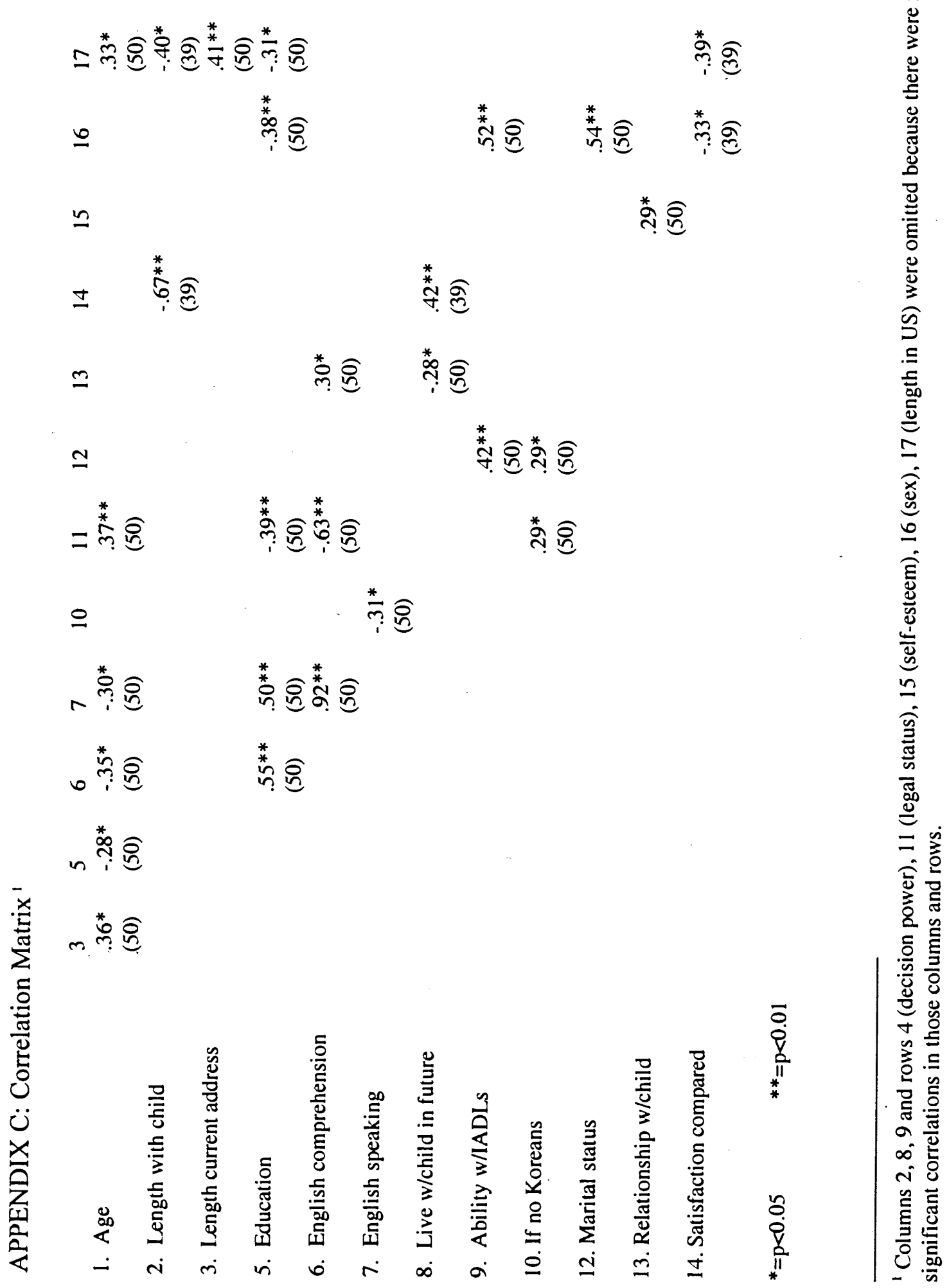

